\title{
Studium petrologiczno-mineralogiczno-geochemiczne skal w profilu dolomitu głównego w otworze Mo-1
}

\author{
Katarzyna Jarmołowicz-Szulc ${ }^{1}$, Aleksandra Kozłowska ${ }^{1}$, Marta Kuberska ${ }^{1}$, Irena Matyasik ${ }^{2}$
}

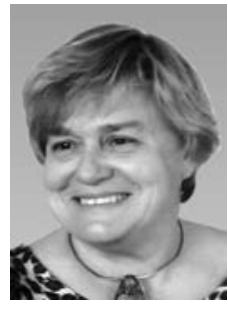

K. Jarmołowicz-Szulc

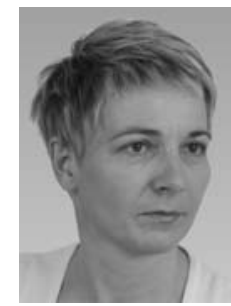

A. Kozłowska

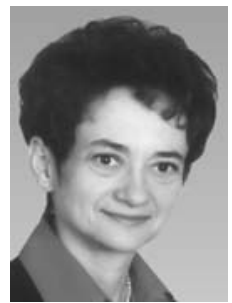

M. Kuberska

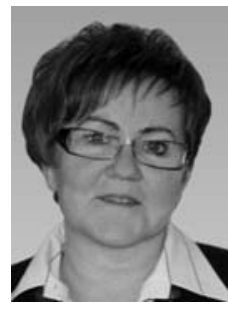

I. Matyasik

A petrological, mineralogical and geochemical study of the Main Dolomite in the Mo-1 borehole. Prz. Geol., 68: 780-792; doi: 10.7306/2020.34

A b s tr a c t. Rocks from the Mo-1 well from the Barnówko-Mostno-Buszewo (BMB) oil and gas field have been studied aiming at constructive results for application in exploration for oil and gas. The study focuses on carbonate deposits from the Main Dolomite horizon, commonly diagenetically altered, where the pore space has been filled by dolomite and anhydrite. Standard petrological analysis was conducted, wide fluid inclusion analyses performed and geochemical character of bitumen determined. Based on microscopic fluorescence studies, three types of fluid inclusions have been distinguished in the vertical column of the well: one-phase non-fluorescent (methane), two-phase non-fluorescent (brine), and two-phase fluorescent inclusions (oil). These three types, further studied microthermometrically, display characteristics of fluid fillings present in the basin and closed as the inclusions in minerals.

Keywords: fluid inclusions, hydrocarbons, oil and gas basin

Poziom dolomitu głównego (Ca2) cechsztynu jest od wielu lat obiektem poszukiwań naftowych w Polsce (np. Karnkowski, 2000, 2007). W tym poziomie węglanowym, w rejonie bloku Gorzowa odkryto wiele niewielkich złóż ropy naftowej i gazu, a w 1993 r. w zachodniej części bloku Gorzowa w poziomie dolomitu głównego Ca2 doszło do odkrycia największego w kraju złoża gazowo-ropnego Barnówko-Mostno-Buszewo (BMB) (Mamczur i in., 1997). Złoże BMB początkowo uznano za trzy oddzielne struktury w dolomicie głównym (Weil i in., 1994). W latach 1994-1995 wykonano trójwymiarowe zdjęcie sejsmiczne (3D) i rozpoznano sterefę złożową struktury, co pozwoliło na wyznaczenie przebiegu i zasięgu występowania strefy barierowej Ca2 (Górski, Trela, 1997). Zarówno wyniki badań sejsmicznych, jak i pomiary geofizyki wiertniczej wykazały, że jest to jedno złoże ropno-gazowe o powierzchni $32 \mathrm{~km}^{2}$, posiadające trzy kulminacje Barnówko, Mostno i Buszewo oddzielone od siebie niewielkimi obniżeniami.

W obrębie kulminacji Mostna, w otworze Mo-1 wykonano badania petrograficzne, inkluzji fluidalnych i geochemiczne bituminów celem prześledzenia wzajemnych relacji pomiędzy mediami złożowymi w basenie, w obrębie minerałów i w odniesieniu do współwystępujących bituminów.

\section{BUDOWA GEOLOGICZNA}

Złoże BMB znajduje się w Wielkopolsce, na bloku Gorzowa, w obrębie utworów cechsztyńskiego dolomitu głównego. Odkryte dotychczas złoża ropy naftowej i gazu ziemnego są związane z elewacjami Barnówka, Mostna,
Buszewa, Gajewa, Różańska oraz Lubiszyna (Peryt, Piątkowski, 1977; Peryt, Dyjaczyński, 1991; Pikulski, 1998; Czekalski i in., 2010). Na podstawie prac wielu autorów (op. cit. Weil i in., 1994; Pikulski, Wolnowski, 2000; Słowakiewicz, Mikołajewski, 2011) można przedstawić następującą charakterystykę geologiczną regionu bloku Gorzowa:

- występujący tutaj wąski i stromy stok platformy węglanowej, mający charakter skarpy, powoduje, że w jego obrębie występują brekcje osuwiskowe;

- na zewnętrznym skraju platformy, od strony otwartego morza istniał prawdopodobnie pas płycizn zbudowanych głównie z piasków oolitowych, które odgrywały role barier. Na zapleczu barier węglanowych tworzyły się w spokojniejszych wodach, osady z większym udziałem mułu węglowego. W obrębie lagun spodziewać się można strefy lokalnych spłyceń, reprezentowanych przez mielizny i ławice oolitowe;

- w obrębie platformy węglanowej sekwencja depozycyjna Ca2 jest złożona $\mathrm{z}$ trzech poziomów osadowych - A, B, C (vide: Pikulski, 1998), powstałych w odmiennych warunkach sedymentacyjnych;

- utwory dolomitu głównego charakteryzują się dobrymi właściwościami zbiornikowymi. W skałach tych dominuje porowatość po rozpuszczonych ziarnach węglanowych, tworzących nieregularne przestrzenie przypominające kawerny, rzadziej otwarte szczeliny, porowatości wynosi 8-14\% (Depowska, Drop, 1997; Mamczur i in., 1997; Pikulski, 1998);

- jak można sądzić na podstawie charakterystyki materii organicznej oraz rozwoju procesów naftowych, migracja i akumulacja węglowodorów w utworach

\footnotetext{
${ }^{1}$ Państwowy Instytut Geologiczny - Państwowy Instytut Badawczy, ul. Rakowiecka 4, 00-975 Warszawa; kjar@pgi.gov.pl

${ }^{2}$ Instytut Nafty i Gazu - Państwowy Instytut Badawczy, ul. Lubicz 25A, 31-503 Kraków.
} 
dolomitu głównego zachodziła co najmniej w dwóch fazach - przed oraz po przebudowie pokredowej; - w złożu - od głębokości 2990,0 do 3047,5 m występuje akumulacja gazu, tzw. czapa gazowa, a poniżej od głębokości 3047,5 do 3107,0 m - ropa naftowa (Karnkowski, 2000). Miąższość strefy złożowej waha się od 33,0 do 83,5 m. Na kulminacji Barnówko i Mostna strefę tę tworzą utwory barierowe, a na kulminacji Buszewa - lagunowe.

\section{PRACE BADAWCZE}

Podstawowe prace badawcze prowadzono wg przyjętego wcześniej (Jarmołowicz-Szulc, 2009), obecnie zmodyfikowanego schematu, który swym zakresem obejmował zarówno badania wstępne (wstępna ocena materiału, selekcja próbek badawczych) oraz charakterystykę inkluzji, jak i badania temperaturowe (zamrażanie, podgrzewanie).

Badania petrograficzne wykonano w siedmiu próbkach skał należących do: anhydrytu podstawowego (pr. 12), dolomitu głównego (pr. 16, 17, 21) i anhydrytu dolnego (pr. 23, 24, 25). W pracy wykorzystano mikroskop polaryzacyjny, katodoluminescencję (CL) i skaningowy mikroskop elektronowy (SEM). W pięciu płytkach cienkich wykonano analizy składu chemicznego węglanów. Na podstawie uzyskanych danych petrograficznych i wybranej literatury (Peryt, Piątkowski, 1977; Gąsiewicz i in., 1998; Sylwestrzak, 1999) podjęto próbę skonstruowania modelu sekwencji diagenetycznej.

Badania geochemiczne, mające na celu określenie charakteru bituminów, przeprowadzono w otworze dla dwóch próbek. Wykonano ekstrakcję bituminów, a następnie ich rozdział na frakcje: nasyconą, aromatyczną, żywice i asfalteny, oraz wykonano analizę dystrybucji biomarkerów z wykorzystaniem chromatografii gazowej sprzężonej ze spektrometrią mas (GC-MS). Spektrogramy masowe frakcji aromatycznej i nasyconej analizowanych próbek otrzymane w trybie pełnego skanowania (TIC) oraz wybranych jonów fragmentacyjnych (SIM) poddawano identyfikacji: hopany $(\mathrm{m} / \mathrm{z}=191)$, sterany $(\mathrm{m} / \mathrm{z}=217)$, związki naftalenowe $(\mathrm{m} / \mathrm{z}=142, \mathrm{~m} / \mathrm{z}=156, \mathrm{~m} / \mathrm{z}=170)$, fenantreny $(\mathrm{m} / \mathrm{z}=$ $=178, \mathrm{~m} / \mathrm{z}=192)$, związki siarkowe (metylodibenzotiofeny $\mathrm{m} / \mathrm{z}=198)$, triaromatyczne steroidy $(\mathrm{m} / \mathrm{z}=231)$. Szczegółowa metodyka badań została przedstawiona przez Matyasik (2009).

Badania inkluzji fluidalnych przeprowadzano mikroskopowo w specjalnych dwustronnie polerowanych płytkach (grubych), głównie z użyciem aparatury zamrażająco-grzewczej firmy Linkam i zestawu fluorescencyjnego Nikon (nadfiolet i światło niebieskie). Do przygotowania wymienionych preparatów zastosowano standardową procedurę przygotowawczą na zimno (Goldstein, Reynolds, 1994).

Interpretację asocjacji inkluzji przeprowadzono na podstawie propozycji Goldsteina i Reynoldsa (1994), przy czym w przypadku konkretnych minerałów i zawartych w nich wrostków kwestię identyfikacji - pierwotne czy wtórne, można przyjąć kryteriach Roeddera (1984), zweryfikowanych przez Goldsteina (2001). Stąd ostateczna interpretacja asocjacji inkluzji została oparta na kryteriach proponowanych przez Goldsteina (2001).

Badania charakteru fluidów zamkniętych w inkluzjach przeprowadzano z użyciem mikroskopu Nikon Eclipse $\mathrm{z}$ dostawką do fluorescencji. Zjawisko fluorescencji bada- no na podstawie wzbudzenia w świetle lampy kwarcowej (por. Jarmołowicz-Szulc, 2016).

Poza prowadzeniem badań tzw. petrografii inkluzji, inkluzje analizowano pod kątem możliwości obecności węglowodorów wyższych w ultrafiolecie i świetle niebieskim. Obraz mikroskopowy zapisywano cyfrowo. Pomiary wykonano pod mikroskopem z okularami o powiększeniu $15 \times$, używając na ogół obiektywów 10×, 20× i 40×. Badania mikrotermometryczne, czyli podgrzewanie i zamrażanie próbek na stoliku zamrażająco-grzewczym, prowadzono z użyciem sterowanego komputerowo stolika firmy LINKAM (prod. 2007). Badania przeprowadzano w zakresie temperatur od pokojowej $\left(19-29^{\circ} \mathrm{C}\right)$ do $150^{\circ} \mathrm{C}$ i do $-70^{\circ} \mathrm{C}$, w przypadku inkluzji wodnych (AQFI) i prawdopodobnych inkluzji węglowodorów ciężkich (HCFI 1) oraz do $-198^{\circ} \mathrm{C}$ w przypadku zamrażania inkluzji węglowodorów lekkich (HCFI 2). Dokładność pomiarów kalibrowano względem powszechnie stosowanych standardów SynFlinc (w zakresie dodatnim $-1^{\circ} \mathrm{C}$, a w zakresie ujemnym $\left.-0,1^{\circ} \mathrm{C}\right)$. Tempo grzania i zamrażania $\mathrm{w}$ urządzeniu Linkam kontrolowano automatycznie i wynosiło ono 20$10^{\circ} \mathrm{C} / \mathrm{min}$., przy zamrażaniu i grzaniu, przechodząc w grzanie w tempie $0,5^{\circ} \mathrm{C} / \mathrm{min}$., w pobliżu charakterystycznych temperatur diagnostycznych, odpowiednio - eutektyku i homogenizacji. Pomiary przeprowadzano pod mikroskopem z okularami o powiększeniu $15 \times$, używając na ogół obiektywu 50×, rzadziej 100×. Przebieg procesów kontrolowano za pomoca specjalistycznego oprogramowania i obserwowano na monitorze komputerowym.

Badania inkluzji fluidalnych wykonywano w węglanach i kwarcu, rzadziej w anhydrycie, stosowano podobne kroki analityczne. Aby wskutek zamrażania nie zmienić objętości inkluzji dwufazowych przeprowadzano najpierw grzanie celem homogenizacji, potem zamrażanie i badania w zakresie temperatur ujemnych (por. Jarmołowicz-Szulc, 2009, 2016, 2019).

Do obliczania izochor, zasolenia i innych parametrów posłużono się zarówno złożonym pakietem FLUIDS (Bakker, 2003; Bakker, Brown, 2003), jak i programem FLINCOR (Brown, 1989), obejmującym mniej skomplikowane układy chemiczne.

\section{WYNIKI BADAŃ SZCZEGÓŁOWYCH W OTWORZE Mo-1}

\section{Pobór próbek skal, wyniki badań fluorescencji i charakter inkluzji fluidalnych}

Otwór jest zlokalizowany na południowej części konturu złoża BMB, w jego środkowej części (ryc. 1). W otworze wiertniczym Mo-1 pobrano osiem próbek rdzenia w zakresie głębokości od 3033,5 m (Ch-13) do 3357,35 m (Ch-23). Wykonano sześć preparatów dwustronnie polerowanych (różna jakość) i dwa preparaty odkryte, a także płytki cienkie do badań petrograficznych.

Badania mineralogiczne prowadzono pod kątem występowania inkluzji fluidalnych i fluorescencji. Obraz inkluzji fluidalnych i ich wzbudzenie w świetle lampy kwarcowej przedstawiono na planszach fotograficznych (ryc. 2 - patrz str. 726, ryc. 3 - patrz str. 793). W tabeli 1 zaprezentowano interpretację wstępnych obserwacji mikroskopowych z odniesieniem do mikrofotografii obu rycin 


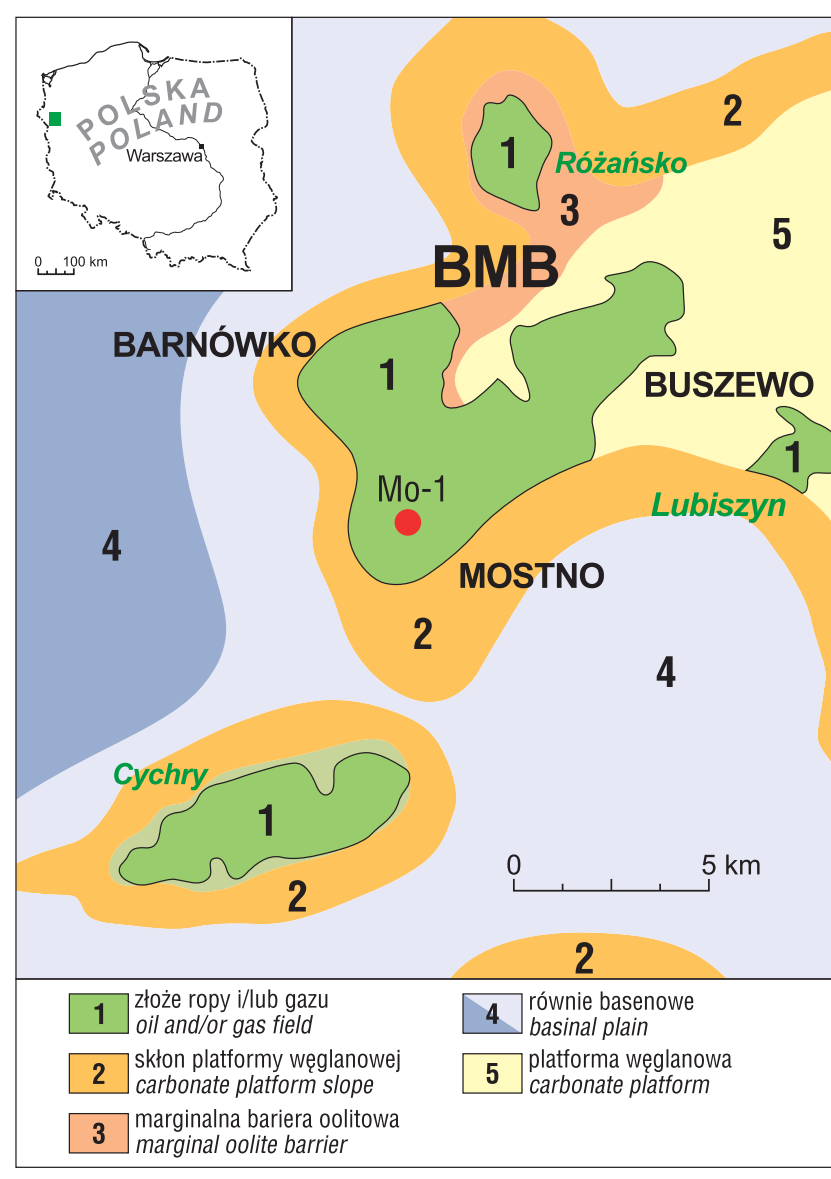

Ryc. 1. Lokalizacja badanego otworu w obrębie złoża ropy i gazu Barnówko-Mostno-Buszewo (układ paleogeograficzny za Wagnerem $\mathrm{i}$ in., 2000; zmodyfikowane)

Fig. 1. Barnówko-Mostno-Buszewo oil and gas field with location of the Mo-1 well (palaeogeography after Wagner et al., 2000; modified)

\section{Analiza petrograficzna wybranych próbek cechsztynu z otworu wiertniczego Mo-1}

Badania petrograficzne pokazują zmienność skał od anhydrytu poprzez dolomit po greinston ooidowy (ryc. 4) w profilu otworu w zakresie głębokości 3027,5-3413,8 m.

\section{Próbka Ch-12, głęb. 3027,50 m}

Anhydryt. Anhydryt bardzo drobno- i drobnokrystaliczny. Niektóre kryształy osiągają wielkość ok. 0,10 mm. Stwierdzono pojedyncze, wydłużone tabliczki osiadające długość do $0,95 \mathrm{~mm}$. W skale występują liczne, nieregularne skupienia dolomitu, występujące w formie cienkich kryształów o przeciętnej długości ok. 0,04 mm (ryc. 5), w obrazie katodoluminescencyjnym świecą żółta, rzadziej pomarańczową barwą. Analiza katodoluminescencyjma ujawniła obecność niewielkiej ilości kaolinitu, który wykazuje świecenie o barwie ciemnoniebieskiej.

\section{Próbka Ch-16, głęb. 3044,40 m}

Dolomit, pakston onkoidowy. Wśród onkoidów przeważają onkoidy złożone, w niektórych jest widoczna struktura tangencjalna. Onkoidy są pozbawione wyodrębnionego jądra lub jest ono zbudowane z mikrosparu dolomitowego. Korteks jest przeważnie mikrytowy. Najprawdopodobniej pierwotnie onkoidy były zbudowane z kalcytu, który uległ dolomityzacji (tab. 2). W obrazie katodoluminescencyjnym dolomit wykazuje barwę czerwoną. Onkoidy spojone są mikrytowym dolomitem oraz anhydrytowym i dolomitowym cementem druzowym (tab. 2).

\section{Próbka Ch-17, głęb. 3056,50 m}

Dolomit, greinston onkoidowy. Skała zbudowana z onkoidów o przeciętnej wielkości ok. 0,30 mm (ryc. 6). Większość z nich jest zrekrystalizowana z zachowanym mikrytowym korteksem. W niektórych onkoidach jest widoczna struktura tangencjalna. Część pustych przestrzeni porowych w obrębie onkoidów może świadczyć o ich selektywnym rozpuszczaniu i powstawaniu porów wewnątrz ziarnowych (Peryt, Piątkowski, 1977). Najprawdopodobniej pierwotnie onkoidy były zbudowane z kalcytu, który uległ dolomityzacji. W obrazie katodoluminescencyjnym dolomit wykazuje barwę malinową. Onkoidy są spojone mikrosparem i sparem dolomitowym. Część przestrzeni porowej wypełnia tabliczkowy anhydryt (ryc. 5A, B). Poza tym występuje kaolinit, który w katodoluminescencji ma barwę ciemnoniebieską. W skale są widoczne pory międzyziarnowe niewypełnione lub tylko częściowo wypełnione.

\section{Próbka Ch-21, głęb. 3096,40 m}

Dolomit, greinston onkoidowy. Skała zbudowana z onkoidów silnie zrekrystalizowanych, z całkowicie zatartą strukturą wewnętrzną. Najprawdopodobniej pierwotnie onkoidy były zbudowane z kalcytu, który uległ dolomityzacji. W obrazie katodoluminescencyjnym dolomit wykazuje barwę malinową. Onkoidy są spojone sparem dolomitowym oraz drobnokrystalicznym anhydrytem. Poza tym są widoczne drobne przestrzenie porowe wewnątrzi międzyziarnowe. W szlifie jest zauważalny kontakt ze skałą dolomitową z onkoidami, z dobrze zachowaną strukturą wewnętrzną (ryc. 6D-F). Część z nich ma budowę złożoną. Większość onkoidów ma część wewnętrzną zbudowaną z mikrosparu i sparu dolomitowego (tab. 2). Wyraźnie widoczny jest korteks mikrytowy. Onkoidy są spojone dolomitem i anhydrytem. Widoczne są pory międzyziarnowe niewypełnione lub tylko częściowo wypełnione.

Próbka Ch-24, głęb. 3402,70 m

Anhydryt. Skała zbudowana w większości z grubokrystalicznych tabliczek anhydrytu. W skale występują liczne smugi i warstewki zbudowane z dolomitu wielkości mikrosparu i sparu (ryc. 6A, B).

\section{Próbka Ch-25, głęb. 3413,80 m}

Greinston ooidowy. Skała złożona z ooidów o strukturze koncentrycznej i radialnej zbudowanych z Fe-kalcytu (tab. 2). W obrazie katodoluminescencyjnym Fe-kalcyt wykazuje barwę czerwono-brunatną lub nie świeci (ryc. 6C-E). Jądra niektórych ooidów stanowią fragmenty bioklastów. Ooidy są zbudowane z mikrytu i mikrosparytu kalcytowego, z obwódkami kalcytu druzowego, dobrze widocznego w obrazie CL. Są one spojone głównie sparytowym Mn-kalcytem (tab. 2), miejscami tabliczkowym anhydrytem. W skale występują żyłki i skupienia wypełnione anhydrytem. W próbce zauważono szef mikrostylolitowy. Obecność stylolitów świadczy m.in. o późnej kompakcji chemicznej.

\section{Wyniki badań bituminów i dystrybucji biomarkerów}

Wynik ekstrakcji bituminów i rozdziału grupowego przedstawiono $\mathrm{w}$ tabeli 3 , a interpretację wyników przeprowadzono na podstawie ogólnie dostępnej bibliografii (np. Radke i in., 1986; Thompson, 1987; Hunt, 1995; George $i$ in., 2002). 
Tab. 1. Wyniki badań próbek z otworu Mo-1

Table 1. Study results for samples from the Mo-1 well

\begin{tabular}{|c|c|c|c|c|}
\hline $\begin{array}{c}\text { Próbka / Glębokość [m] } \\
\text { Sample / Depth [m] }\end{array}$ & $\begin{array}{c}\text { Litostratygrafia } \\
\text { Lithostratigraphy }\end{array}$ & $\begin{array}{l}\text { Rodzaj preparatu } \\
\text { Sample type }\end{array}$ & $\begin{array}{l}\text { Obserwacje } \\
\text { Observations }\end{array}$ & $\begin{array}{l}\text { Fluorescencja / Uwagi } \\
\text { Fluorescence / Remarks }\end{array}$ \\
\hline & $\begin{array}{l}\text { ahydryt górny } \\
\text { Upper Anhydrite }\end{array}$ & & & \\
\hline Ch-12/3027,5 & $\begin{array}{l}\text { dolomit główny } \\
\text { Main Dolomite }\end{array}$ & $\begin{array}{l}\text { c. skała } \\
\text { whole rock }\end{array}$ & & $\begin{array}{l}\text { badania bituminów } \\
\text { bitumen analyses }\end{array}$ \\
\hline Ch-13 / 3033,5 & $\begin{array}{l}\text { dolomit główny } \\
\text { Main Dolomite }\end{array}$ & $\mathrm{FI}^{*}$ & $\begin{array}{l}\text { anhydryt brązowo-biały, węglany?, fauna; } \\
\text { inkluzje małe - w węglanie } \\
\text { huge sample in brown-white colours } \\
\text { anhydrite, carbonates?, fauna; } \\
\text { small inclusions in carbonate }\end{array}$ & $\begin{array}{l}\text { niebieskawe } \\
\text { świecenie - śmieci } \\
\text { czy FI (?); ryc. } 2 \text {. } \\
\text { bluish luminescence - } \\
\text { ash or FI (?); Fig. } 2 .\end{array}$ \\
\hline Ch-14 / 3035,3 & $\begin{array}{l}\text { dolomit główny } \\
\text { Main Dolomite }\end{array}$ & $\mathrm{FI}^{*}$ & $\begin{array}{l}\text { wapień organodetrytyczny (?) z jasnymi } \\
\text { skupieniami i żyłkami; } \\
\text { w anhydrycie - drobne FI } \\
\text { organodetrital carbonate with bright } \\
\text { accumulations and veinlets }\end{array}$ & $\begin{array}{l}\text { świecenie } \\
\text { o niezdefiniowanym } \\
\text { źródle } \\
\text { undefined } \\
\text { luminescence }\end{array}$ \\
\hline Ch-15 / 3039,3 & $\begin{array}{l}\text { dolomit główny } \\
\text { Main Dolomite }\end{array}$ & $\mathrm{FI}^{*}$ & $\begin{array}{l}\text { jaśniejsze i ciemniejsze cześci skały; } \\
\text { preparat w kilku fragmentach; w jasnej } \\
\text { cześci dziobate tworki (?); trafiaja sie } \\
\text { inkluzje dwufazowe - bardzo małe (ob. } \\
\text { 40×); w jasnych partiach jednofazowe FI - } \\
\text { krople } \\
\text { bright and dark parts of the rock; sample in } \\
\text { pieces; some undefined objects (?); } \\
\text { occasionally - very small two-phase } \\
\text { inclusions (objective 40×) }\end{array}$ & $\begin{array}{l}\text { na ogół brak; obraz } \\
\text { ciemny, czasem } \\
\text { rozświetlony; ryc. } 2 \\
\text { generally lack of inc- } \\
\text { lusions; dark image, } \\
\text { occasionally enlighte- } \\
\text { ned; Fig. } 2 \\
\text { Ch-16 i Ch-17 / 3056,5 } \\
\text { / badania petrol. } \\
\text { /petrological studies }\end{array}$ \\
\hline $\begin{array}{l}\text { Ch-18 / } 3066,5 \\
\text { skała przesycona } \\
\text { weglowodorami } \\
\text { rock saturated with } \\
\text { hydrocarbons }\end{array}$ & $\begin{array}{l}\text { dolomit główny } \\
\text { main dolomite }\end{array}$ & ODKR & $\begin{array}{l}\text { bardzo drobnokrystaliczna skała; bioklasty } \\
\text { zanhydrytyzowane - w środku jasnych } \\
\text { wypełnień - tworki kropelkowe } \\
\text { w nagromadzeniach - (?) FI jednofazowe? } \\
\text { very finely crystalline rock; anhydritized } \\
\text { bioclasts - drop objects in the cente of } \\
\text { bright infilling - (?) one-phase FI? }\end{array}$ & $\begin{array}{l}\text { / Próbki Ch-17/ } \\
3056,5 \\
\text { i Ch-21/ badania } \\
\text { bituminów } \\
\text { / bitumen analyses }\end{array}$ \\
\hline $\begin{array}{l}\text { Ch-19/3069,8 } \\
\text { skała przesycona } \\
\text { weglowodorami } \\
\text { rock saturated with } \\
\text { hydrocarbons }\end{array}$ & $\begin{array}{l}\text { dolomit główny } \\
\text { Main Dolomite }\end{array}$ & ODKR & $\begin{array}{l}\text { wyraźnie w jasnych kryształach bardzo małe } \\
\text { FI jednofazowe } \\
\text { very small one-phase inclusions in bright } \\
\text { crystals }\end{array}$ & \\
\hline Ch-20 / 3090,45 & $\begin{array}{l}\text { dolomit główny } \\
\text { Main Dolomite }\end{array}$ & $\mathrm{FI}^{*}$ & $\begin{array}{l}\text { wapień ooidowy mało zmieniony; FI - nie } \\
\text { widać; ciemne wrostki lub wypełnienia } \\
\text { ooidów wykazują niebieskawą fluorescencję } \\
\text { slightly altered ooid limestone; FI - not } \\
\text { seen; dark inclusions or infilling of ooids } \\
\text { display bluish fluorescence }\end{array}$ & $\begin{array}{l}\text { silna niebieska } \\
\text { fluorescencja - ale nie } \\
\text { FI } \\
\text { Ch-21 / 3096,4 / } \\
\text { analiza petrol. i anali- } \\
\text { za bituminów; } \\
\text { spag Ca2 - } 3115 \mathrm{~m} \\
\text { petrological and bitu- } \\
\text { men analyses } \\
\text { Ca2 floor }-3115 \mathrm{~m} \\
\end{array}$ \\
\hline Ch-22 / 3116,7 & $\begin{array}{l}\text { anhydryt dolny } \\
\text { Lower Anhydrite }\end{array}$ & $\mathrm{FI}^{*}$ & $\begin{array}{l}\text { bardzo zmieniony wapień - ooidy mętne; } \\
\text { dużo wykrystalizowanego anhydrytu } \\
\text { highly altered limestone - not clear ooids; } \\
\text { abundant anhydrite }\end{array}$ & \\
\hline Ch-23 / 3357,35 & $\begin{array}{l}\text { anhydryt dolny } \\
\text { Lower Anhydrite }\end{array}$ & $\mathrm{FI}^{*}$ & $\begin{array}{l}\text { słaby preparat - jasny w kawałeczkach; } \\
\text { piekne inkluzje jedno- i dwufazowe } \\
\text { bad sample - bright in pieces; one- } \\
\text { and two-phase inclusions }\end{array}$ & $\begin{array}{l}\text { ryc. } 3 \\
\text { Fig. } 3\end{array}$ \\
\hline
\end{tabular}

Oznaczenie skrótów: FI* - preparat dwustronnie polerowany; ODKR - odkryta płytka cienka; FI - inkluzje fluidalne.

Explanation of abbreviations: FI*-double-sided-polished sample; ODKR-uncovered thin section; FI-fluid inclusions.

Próbka Ch-21 (głębokość 3096,0 m) wykazuje najwyższe nasycenie substancją bitumiczną - 341 ppm (tab. 3).

Próbka Ch-12 oraz Ch-17 wykazują znacznie niższe nasycenie substancją bitumiczną, odpowiednio $66 \mathrm{ppm}$ i 214 ppm (tab. 3). W składzie frakcyjnym ekstrahowalnej substancji organicznej w przewadze występują węglowodory nasycone, stanowiące ok. 58-75\%.

Wysokie wskaźniki ESO/TOC oraz HC/HZ mogą świadczyć o wysokiej dojrzałości materii organicznej i akumulacji węglowodorów.

Analizę chromatograficzną GC-MS wykonano dla frakcji nasyconej węglowodorów, a chromatogramy przedstawiono na ryc. $7 \mathrm{~A}, \mathrm{~B}$.
Badane próbki wykazują niewielkie zróżnicowanie pod względem dystrybucji $n$-alkanów i izoprenoidów, co wpływa także na wartości obliczonych wskaźników geochemicznych (tab. 4). Rozkład $n$-alkanów mieści się w zakresie od $n-\mathrm{C}_{17}$ do $n-\mathrm{C}_{36(39)}$, a maksimum dystrybucji przypada na alkan $n-\mathrm{C}_{26}$. Wartości wskaźnika $\mathrm{Pr} / \mathrm{Ph}$ są przedstawione w tabeli 4, przy czym należy pamiętać, że badane próbki wykazują ogólnie niską zawartość materii organicznej, a wartości tego wskaźnika w ich przypadku mogą być zaniżone ze względu na to, że łańcuch $n$-alkanów rozpoczyna się dopiero od $n-\mathrm{C}_{17}$.

Wśród biomarkerów pozwalających na bardziej precyzyjne oznaczenie substancji źródłowej, zidentyfikowano 

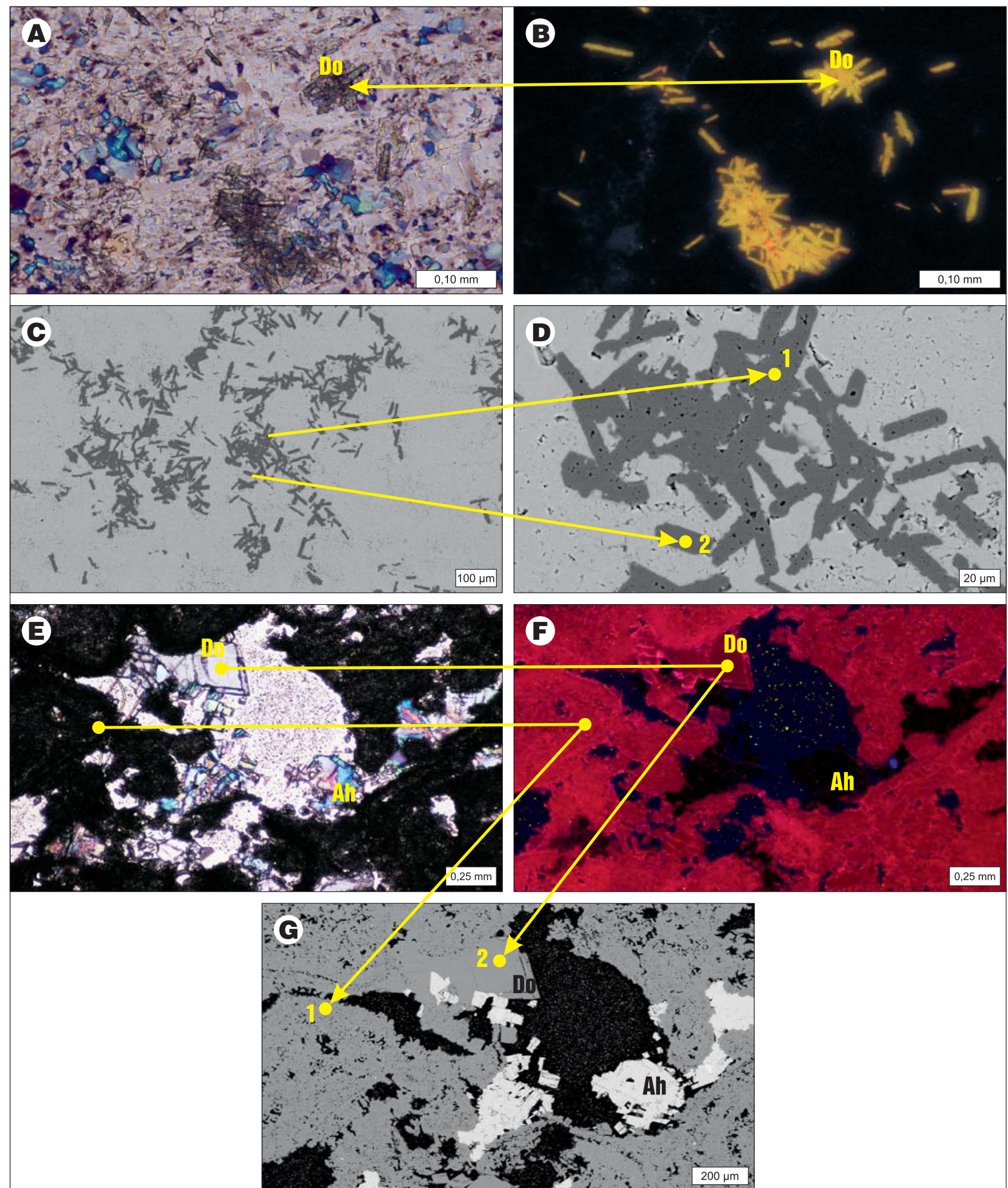

Ryc. 4. Anhydryt i pakston onkoidowy. Anhydryt ze skupieniami dolomitu (Do): A - obraz PL, bez analizatora; B - obraz w CL skały z ryc. A; dolomit (Do) wykazuje świecenie w barwie żółtej i pomarańczowej, anhydryt nie wykazuje luminescencji; $\mathbf{C}$ - formy słupkowe dolomitu tworzące skupienia; obraz BSE; D - fragment skały z ryc. C; słupki dolomitu z zaznaczonymi miejscami analiz chemicznych - 1 i 2 (tab. 2); obraz BSE. Kryształy dolomitu (Do) i anhydrytu (Ah) w przestrzeni porowej w dolomitowym pakstonie onkoidowym: E - obraz PL, bez analizatora; F - obraz w CL skały z fot. E; dolomit (Do) wykazuje świecenie w barwie brunatno-czerwonej i czerwonej, anhydryt (Ah) nie wykazuje luminescencji, kaolinit ma barwę ciemnoniebieską; G - fragment skały z ryc. E i F; anhydryt (Ah) oraz mikrytowy dolomit w onkoidzie i romboedr dolomitu (Do), z zaznaczonymi miejscami analiz chemicznych - 1 i 2 (tab. 2); obraz BSE Fig. 4. Anhydrite and oncoid packstone. Anhydrite with aggregates of dolomite (Do): $\mathbf{A}$ - transmitted polarized light; one polarizer; $\mathbf{B}$ - CL image of the rock from Fig. A; dolomite (Do) shows yellow and orange luminescence, anhydrite - non-luminescent; $\mathbf{C}$ - prismatic forms of dolomite that form aggregates; BSE image; D - rock fragment from Fig. C; dolomite prisms with points of chemical analyses -1 and 2 (Table 2); BSE image. Dolomite (Do) and anhydrite (Ah) crystals in pore space in dolomitic oncoid packstone: $\mathbf{E}$ - transmitted polarized light; one polarizer; F-CL image of rock from Fig. E; dolomite (Do) displays brown-red or red luminescence, anhydrite (Ah) shows no luminescence, kaolinite is dark blue in colour; $\mathbf{G}$ - fragment from Figs. E and F; anhydrite (Ah), micritic dolomite oncoid, and dolomite (Do) rhombohedron, with points of chemical analyses - 1 and 2 (Table 2); BSE image 

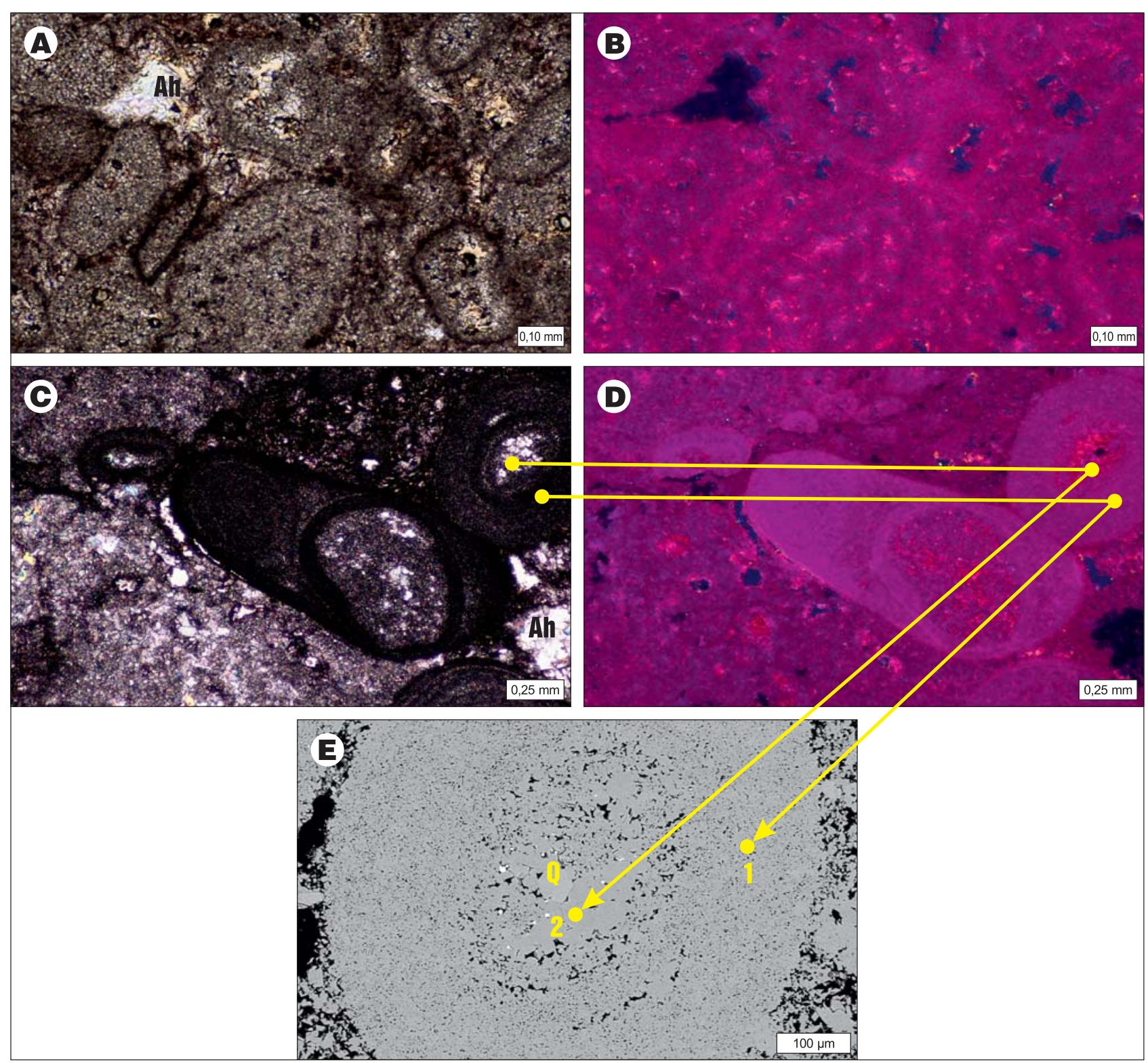

Ryc. 5. Dolomitowy greinston onkoidowy: A - widoczny anhydryt (Ah); obraz PL, bez analizatora; B - obraz w CL skały z ryc. A; dolomit wykształcony w postaci mikrosparu i sparu wykazuje luminescencję w barwie malinowej, kaolinit w barwie ciemnoniebieskiej, anhydryt nie świeci; C - obraz PL, bez analizatora; D - obraz w CL skały z ryc. C; dolomit wykształcony w postaci mikrosparu i sparu wykazuje luminescencję w barwie malinowej, kaolinit w barwie ciemnoniebieskiej, a anhydryt nie świeci; $\mathbf{E}$ - fragment skały z ryc. C i D; kwarc (Q) w jądrze onkoidu oraz mikrytowy i sparytowy dolomit, z zaznaczonymi miejscami analiz chemicznych - 1 i 2 (tab. 2); obraz BSE

Fig. 5. Dolomitic oncoid grainstone: $\mathbf{A}$ - anhydrite (Ah); $\mathbf{B}-\mathrm{CL}$ image of the rock from Fig. A; dolomite shows yellow-orange luminescence, anhydrite is non-luminescent; $\mathbf{C}$ - transmitted polarized light, one polarizer; $\mathbf{D}-\mathrm{CL}$ image of the rock from Fig. C; dolomite microspar and spar display pinky red luminescence, kaolinite - dark blue, anhydrite - no luminescence; $\mathbf{E}$ - rock fragment from Figs. C and D; quartz (Q) in the core of oncoid and micritic and sparry dolomite, places of chemical analyses - 1 and 2 (Table 2); BSE image

w niewielkich ilościach hopany i sterany oraz w stosunkowo dużych ilościach tricykliczne terpeny, co wskazuje na salinarne, ewaporatowe środowisko sedymentacji, a także na względnie wysoką dojrzałość materii organicznej, zwłaszcza w próbce Ch-21 z głębokości 3096 m (ryc. 8C, D). Ze względu na niewielkie ilości hopanów i steranów nie obliczono wskaźników na nich opartych.

Na rycinie 8 przedstawiono spektrogramy masowe frakcji aromatycznej. Na podstawie rozkładu fenantrenu oraz jego metylowych pochodnych obliczono wartość wskaźnika MPI-1 (tab. 5) (Radke i in., 1986). Jego wartość wzrasta ze wzrostem stopnia dojrzałości, osiągając maksimum w oknie ropnym, a potem maleje. Na wartość tego wskaźnika mają wpływ zmiany facjalne środowiska.

Na podstawie MPI-1 można obliczyć wartość refleksyjności witrynitu $R_{c} \%$ (Radke $i$ in., 1986). Obliczona wartość $R_{(\text {MPI-1) }}$ jest podobna w obu próbkach i odpowiada $R_{0}$ w zakresie $0,72 \%$. Daje się tu zauważyć różnica pomiędzy wskaźnikami $\mathrm{R}_{\mathrm{MPI}-1}$ a $\mathrm{R}_{\mathrm{MDR}}$. Wartości obliczone na podstawie MDR są w tym wypadku bardziej wiarygodne $\mathrm{z}$ uwagi na węglanowy charakter skał macierzystych i wysoką zawartość związków siarki.

W badanych próbkach występują również aromatyczne związki siarki, które są obecne w dużych ilościach 


\begin{tabular}{|c|c|c|c|c|c|c|c|c|c|}
\hline 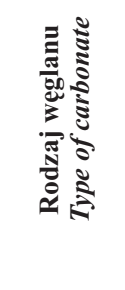 & 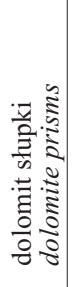 & 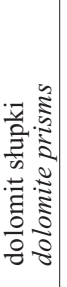 & 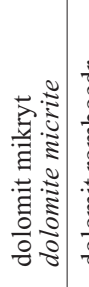 & 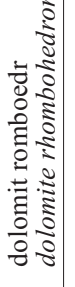 & 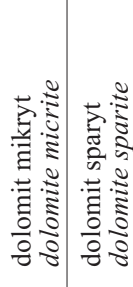 & 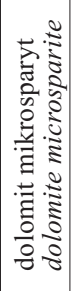 & 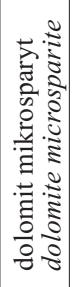 & 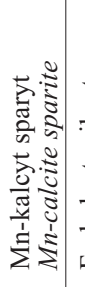 & 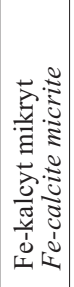 \\
\hline 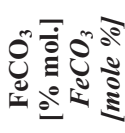 & $\because$ & $\overrightarrow{0}$ & $\overline{0}$ & $\therefore$ & $\because$ & $\overrightarrow{0}$ & : & $\therefore$ & $\tilde{o}$ \\
\hline 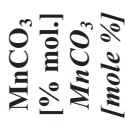 & $m_{0}^{m}$ & $\therefore$ & : & : & $\therefore$ & $\because$ & $\overrightarrow{0}$ & $\vec{i}$ & 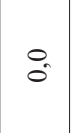 \\
\hline 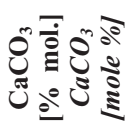 & $\begin{array}{l}\infty \\
\text { if } \\
\text { in }\end{array}$ & $\begin{array}{l}+ \\
\text { s. } \\
n\end{array}$ & $\begin{array}{l}\infty \\
\stackrel{+}{+}\end{array}$ & $\hat{b}$ & in & $\begin{array}{l}\dot{\infty}_{\hat{n}} \\
\text { in }\end{array}$ & $\overrightarrow{i^{0}}$ & $\begin{array}{l}n \\
\text { s. }\end{array}$ & مू \\
\hline 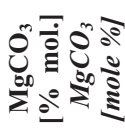 & शे & $\begin{array}{l}n \\
\tilde{q}\end{array}$ & $\bar{y}$ & $\begin{array}{l}m \\
\tilde{f}\end{array}$ & $\stackrel{m}{f}$ & $\frac{0}{\vec{F}}$ & $\begin{array}{l}\infty \\
\vec{F}\end{array}$ & $\stackrel{\Xi}{-}$ & $\stackrel{0}{\circ}$ \\
\hline 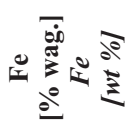 & $\stackrel{8}{\circ}$ & $\begin{array}{l}\text { Oे. } \\
0\end{array}$ & $\begin{array}{l}\stackrel{0}{0} \\
0\end{array}$ & $\begin{array}{l}\tilde{O} \\
\tilde{0}\end{array}$ & तु & $\begin{array}{l}0 \\
0 \\
0\end{array}$ & $\begin{array}{l}8 \\
0\end{array}$ & : & $\stackrel{\simeq}{0}$ \\
\hline$\sum_{\overline{0}}^{\overline{\delta 0}}$ & $\stackrel{0}{\stackrel{0}{0}}$ & 8 & 8 & 8 & $\begin{array}{l}8 \\
0\end{array}$ & $\overrightarrow{0}$ & $\begin{array}{l} \pm \\
0 \\
0\end{array}$ & $\stackrel{\vec{\sigma}}{-}$ & $\begin{array}{l}8 \\
0\end{array}$ \\
\hline 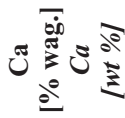 & $\begin{array}{l}\infty \\
\stackrel{\sim}{N} \\
\stackrel{+}{n}\end{array}$ & $\begin{array}{l}\hat{\tilde{z}} \\
\hat{i}\end{array}$ & 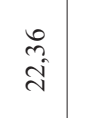 & $\begin{array}{l}3 \\
i \\
i\end{array}$ & 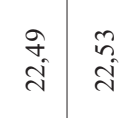 & 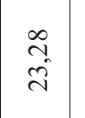 & $\begin{array}{l}3 \\
3\end{array}$ & 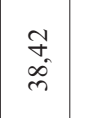 & $\begin{array}{l}n \\
\text { nे } \\
\text { mे }\end{array}$ \\
\hline$\sum^{\infty} \sum^{\infty}$ & $\stackrel{E}{i}$ & ते & $\frac{\Delta}{m}$ & 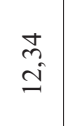 & 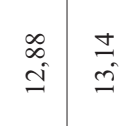 & $\begin{array}{l}\infty \\
\stackrel{\infty}{n} \\
=\end{array}$ & $\overrightarrow{\bar{a}}$ & $\overrightarrow{\sigma_{0}}$ & $\stackrel{\Rightarrow}{0}$ \\
\hline 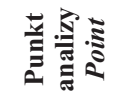 & - & N & - & $\sim$ & $\sim$ & - & $\sim$ & - & $N$ \\
\hline 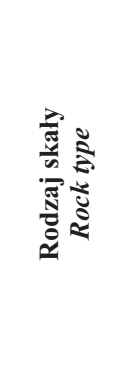 & \multicolumn{2}{|c|}{ 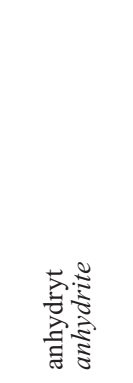 } & \multicolumn{2}{|c|}{ 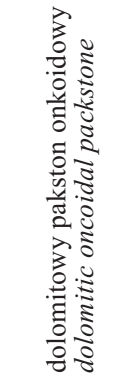 } & 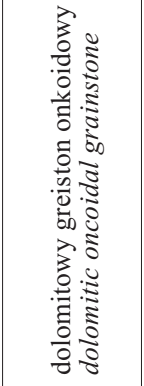 & \multicolumn{2}{|c|}{ 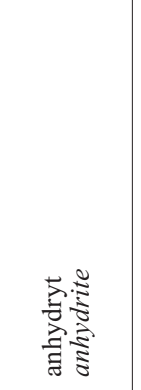 } & \multicolumn{2}{|c|}{ 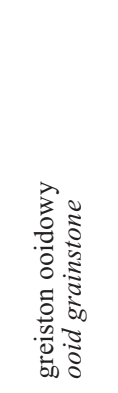 } \\
\hline 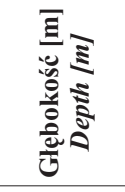 & \multicolumn{2}{|c|}{$\begin{array}{l}\text { ñ } \\
\text { ते } \\
\text { d }\end{array}$} & \multicolumn{2}{|c|}{$\begin{array}{l}\text { q } \\
\text { d } \\
\stackrel{d}{0}\end{array}$} & $\begin{array}{l}\text { q̊. } \\
\text { ôे } \\
\text { p }\end{array}$ & \multicolumn{2}{|c|}{$\underset{m}{m}$} & \multicolumn{2}{|c|}{$\begin{array}{l}\infty \\
\infty \\
\stackrel{m}{7} \\
\dot{m}\end{array}$} \\
\hline 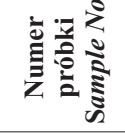 & \multicolumn{2}{|c|}{$\simeq$} & & $\bar{v}$ & \multicolumn{2}{|c|}{$\tilde{\lambda}$} & \multicolumn{2}{|c|}{$\stackrel{\imath}{a}$} \\
\hline
\end{tabular}

(ryc. 8C, D) i na ich podstawie obliczono wskaźnik dojrzałości MDR i $\mathrm{R}_{(\mathrm{MDR})}$.

W próbkach stwierdzono niskie zawartości triaromatycznych steroidów (TAS), co koreluje się ze śladowymi ilościami steranów.

\section{Wyniki badań inkluzji fluidalnych}

W wyniku omówionych powyżej badań fluorescencji zostały wyróżnione następujące typy inkluzji fluidalnych: jednofazowe nie wykazujące fluorescencji, dwufazowe wykazujące wzbudzenie i dwufazowe nie wykazujące wzbudzenia. Dla takich grup inkluzji prowadzono badania mikrotermometryczne, w efekcie których uzyskano następujące wartości temperatur: temperaturę homogenizacji (Th), temperaturę eutektyku (Te), temperaturę topnienia lodu $(\mathrm{Tm})$ i temperaturę klatratu (Tc). Procesy podgrzewania i zamrażania przeprowadzono w zakresie temperatur od 200 do $-190^{\circ} \mathrm{C}$. Wyniki badań mikrotermometrycznych inkluzji fluidalnych zaprezentowano w tabeli 6 .

W otworze Mo-1 w anhydrycie w próbce Ch-15 z głębokości 3039,3 m występują jasne, pozornie jednofazowe, w rzeczywistości zaś dwufazowe inkluzje tworzące asocjację co najmniej siedmiu wrostków (FIA) (ryc. 9). Są one wyraźnie porozciagane. Badania pęcherzyka największej z tych inkluzji przeprowadzano w zakresie ujemnych temperatur. Ma ona wielkość ok. 0,015 mm, a sam pęcherzyk zajmuje prawie $3 / 4$ objętości. Inkluzję zamrożono do temperatury $-196^{\circ} \mathrm{C}$, co spowodowało wydzielenie się $\mathrm{w}$ pęcherzyku dodatkowej fazy $\mathrm{w}$ zakresie poniżej $-100^{\circ} \mathrm{C}$ (ryc. 9C), a następnie sukcesywnie podgrzewano celem homogenizacji faz. Homogenizacja nastąpiła w temperaturze $-138,5^{\circ} \mathrm{C}$ (ryc. 9D). Dalsze podgrzewanie inkluzji nie ujawniło innych procesów w jej wnętrzu w zakresie ujemnych temperatur. Cała inkluzja homogenizowała w fazę gazową w temperaturze $166,9^{\circ} \mathrm{C}$. Zamrażanie i homogenizacja w próbce Ch-13 z gł. 3031,5 m pokazują, że temperatury homogenizacji mieszczą się w przedziale $116-133^{\circ} \mathrm{C}$, a temperatura topnienia lodu wynosi $-3,8^{\circ} \mathrm{C}$ (tab. 6 i 7).

\section{DYSKUSJA WYNIKÓW I WNIOSKI}

Przeprowadzone studium minerałów, bituminów i inkluzji fluidalnych obejmuje próbki skał z otworu wiertniczego z jednej z trzech kulminacji złoża BMB w zakresie głębokości ograniczonym dostępnością rdzenia. Badania wykonano dla różnych typów spoiw i minerałów ze skał węglanowych poziomów anhydrytu i dolomitu głównego.

Badano osady węglanowe dolomitu głównego, często zmienione diagenetycznie, gdzie pierwotne przestrzenie porowe zostały zabudowane dolomitem i anhydrytem. Na ogół są to skały beżowe i ciemnobrązowe o strukturze ziarnistej, częściowo przekrystalizowanej, niekiedy pelityczne, drobnoziarniste. 

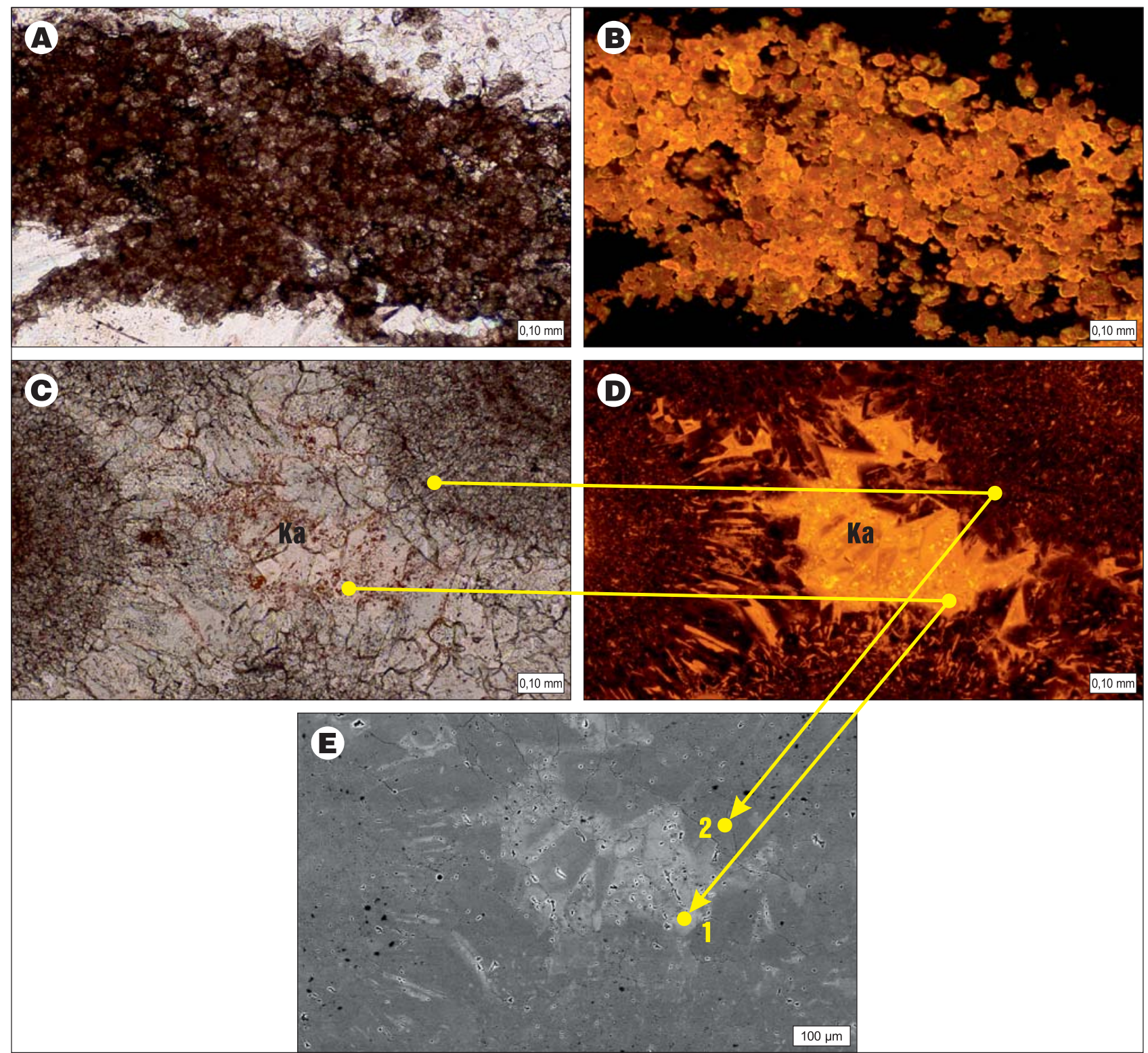

Ryc. 6. Obraz skał w najniższej części profilu otworu wiertniczego Mo-1. Warstewka dolomitowa w skale anhydrytowej: A-obraz PL, bez analizatora; B - obraz w CL skały z ryc. A; dolomit wykazuje luminescencję w barwie żółto-pomarańczowej, anhydryt nie świeci. Greiston ooidowy spojony sparytowym kalcytem (Ka): C - obraz PL, bez analizatora; D - obraz w CL skały z ryc. C; kalcyt (Ka) sparytowy wykazuje luminescencję pomarańczową i żółtą, a mikrytowy brunatno-czerwoną lub nie świeci; $\mathbf{E}-$ fragment skały z ryc. C i D, z zaznaczonymi miejscami analiz chemicznych - 1 i 2 (tab. 1); obraz BSE

Fig. 6. Image of rocks from the lowest part of the Mo-1 well. Dolomite layer in anhydrite rock: A-transmitted polarized light, one polarizer; B - CL image of the rock from Fig. A; dolomite shows yellow-orange luminescence, anhydrite is non-luminescent. Ooid grainstone cemented by sparitic calcite $(\mathrm{Ka})$ : $\mathbf{C}$ - transmitted polarized light, one polarizer; $\mathbf{D}-\mathrm{CL}$ image of the rock from Fig. C; sparitic calcite (Ka) displays orange and yellow luminescence, micritic calcite shows either brown-red or no luminescence; $\mathbf{E}$ - fragment of rock from Figs. C and D, with points of chemical analyses - 1 and 2 (Table 1); BSE image

\section{Historia diagenezy skal}

Obserwacje petrograficzne pozwoliły wyróżnić różnorodne minerały podlegające $\mathrm{w}$ przeszłości przemianom diagenetycznym. Głównymi minerałami budującymi opisywane skały w otworze Mo-1 są kalcyt i dolomit oraz anhydryt. Cementacja zachodziła etapowo, tworząc kilka generacji tych minerałów (ryc. 10). W historii diagenezy można wyróżnić eo- i mezodiagenezę. Do wczesnych cementów należą kalcytowe cementy: mikrytowy, druzowy i obwódkowy. W późniejszym etapie tworzą się cementy sparytowe i blokowe (kalcyt, dolomit, anhydryt), wy- pełniające puste przestrzenie porowe lub mikroszczeliny. Skały dolomitowe sa najprawdopodobniej produktem dolomityzacji wapieni. Trzy próbki reprezentują skałę anhydrytową. Anhydryt w pozostałych próbkach występuje jako późniejszy składnik cementu skał węglanowych. Obok cementacji ważnym procesem diagenetycznym było rozpuszczanie cementów i ziarn węglanowych, które miało miejsce w eo- i mezodiagenezie. Efektem tego procesu są obserwowane puste przestrzenie między- i wewnątrzziarnowe. W skałach obserwowano efekty kompakcji mechanicznej (spłaszczone ziarna onkoidów i mikroszczeliny) i kompakcji chemicznej (stylolity). 
Tab. 3. Wyniki ekstrakcji bituminów i ich rozdziału grupowego

Table 3. Results of analyses of extractable organic matter (EOM)

\begin{tabular}{|c|c|c|c|c|c|c|c|c|}
\hline \multirow{3}{*}{$\begin{array}{l}\text { Próbka } \\
\text { Sample }\end{array}$} & \multirow{3}{*}{$\begin{array}{c}\text { TOC } \\
{[\% \mathrm{wag}]} \\
{[\text { wt \%] }}\end{array}$} & \multirow{3}{*}{$\begin{array}{l}\text { ESO } \\
{[\mathrm{ppm}]}\end{array}$} & \multicolumn{4}{|c|}{$\begin{array}{l}\text { Sklad grupowy bituminów [\%] } \\
\text { Group composition of bitumen }\end{array}$} & \multirow{3}{*}{$\frac{\text { ESO }}{\text { TOC }}$} & \multirow{3}{*}{$\frac{\mathrm{HC}}{\mathrm{HZ}}$} \\
\hline & & & \multicolumn{2}{|c|}{$\begin{array}{l}\text { węglowodory } \\
\text { hydrocarbons }\end{array}$} & \multicolumn{2}{|c|}{$\begin{array}{c}\text { heterozwiązki } \\
\text { heterocompounds }\end{array}$} & & \\
\hline & & & $\begin{array}{l}\text { nasycone } \\
\text { saturated }\end{array}$ & $\begin{array}{c}\text { aromatyczne } \\
\text { aromatic }\end{array}$ & $\begin{array}{l}\text { żywice } \\
\text { resins }\end{array}$ & $\begin{array}{c}\text { asfalteny } \\
\text { asphaltenes }\end{array}$ & & \\
\hline Ch-17 & 0,11 & 194 & 58,9 & 9,6 & 21,1 & 10,3 & 194 & 2,2 \\
\hline Ch-12 & 0,11 & 66 & \multicolumn{5}{|c|}{$\begin{array}{l}\text { zbyt niska zawartość do wykonania SARA - b.o. } \\
\text { too low content }\end{array}$} & b.o. \\
\hline Ch-21 & 0,46 & 341 & 74,8 & 13,2 & 8,1 & 3,9 & 341 & 9,8 \\
\hline
\end{tabular}

TOC [\% wag.] - całkowita zawartość węgla organicznego, ESO [ppm] - ekstrahowalna substancja organiczna, b.o. - brak oznaczenia, HC - węglowodory, $\mathrm{HZ}$ - heterozwiązki.

TOC - total organic carbon, ESO - extractable organic matter, b.o. - not analysed, HC - hydrocarbons, HZ - heterocompounds.
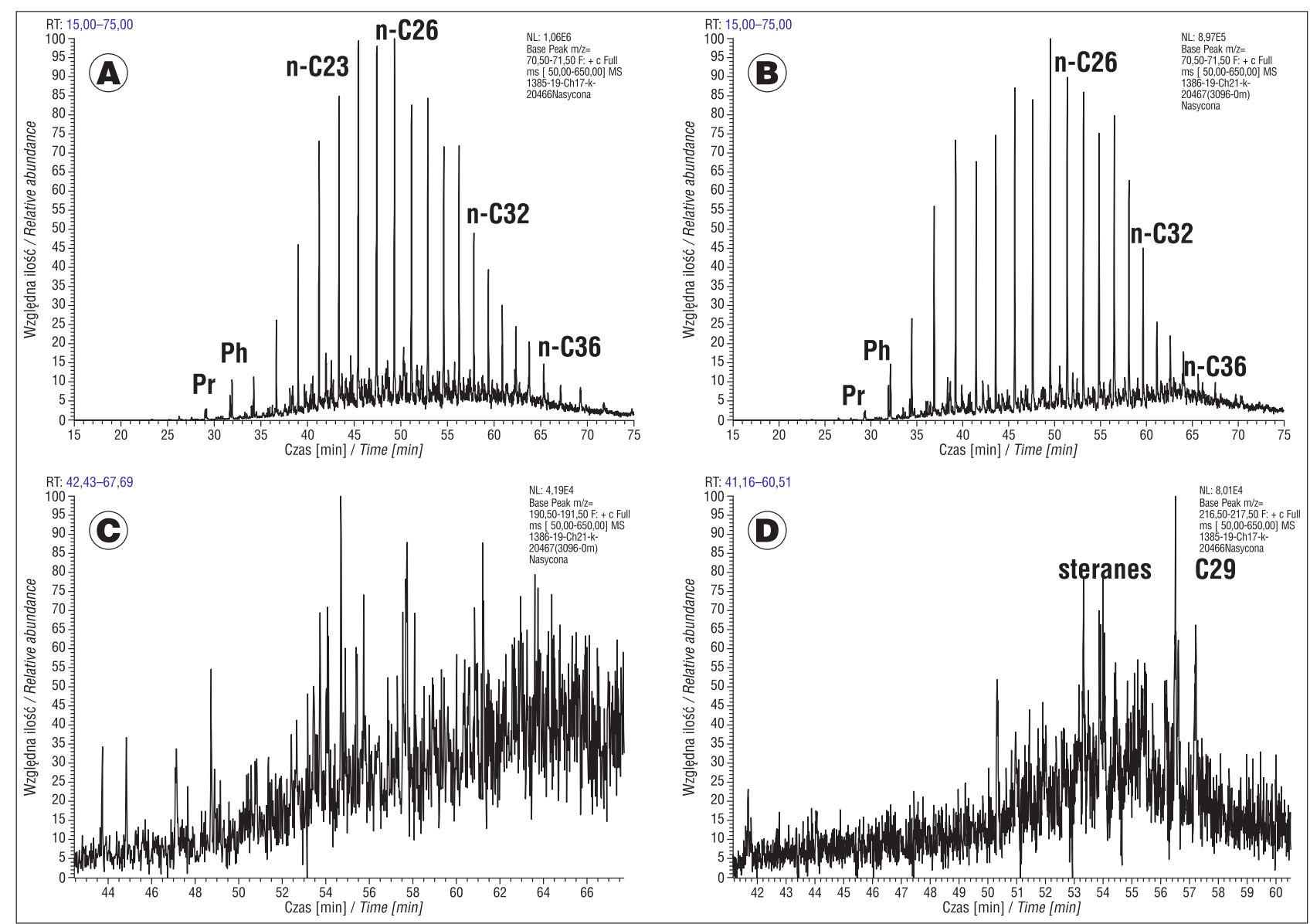

Ryc. 7. Skład frakcji nasyconej: A - skład węglowodorów frakcji nasyconej wydzielonej z ekstraktu bitumicznego próbki Ch-17, ilustrujący zakres węglowodorów od $n$ - $\mathrm{C}_{17}$ do $n$ - $\mathrm{C}_{36} ; \mathbf{B}$ - skład węglowodorów frakcji nasyconej wydzielonej z ekstraktu bitumicznego próbki Ch-21, ilustrujący zakres węglowodorów od $n$ - $\mathrm{C}_{17}$ do $n$ - $\mathrm{C}_{36} ; \mathbf{C}-\operatorname{rozkład~hopanów~}(\mathrm{m} / \mathrm{z}=191)$ w próbce ekstraktu bitumicznego (Ch-21); $\mathbf{D}$ - rozkład steranów $(\mathrm{m} / \mathrm{z}=217)$ w próbce ekstraktu bitumicznego $(\mathrm{Ch}-17)$

Fig. 7. Composition of saturated fraction: $\mathbf{A}$ - composition of hydrocarbons in the saturated fraction separated from the bitumen extract of sample Ch-17 showing a hydrocarbon interval from $n-\mathrm{C}_{17}$ to $n-\mathrm{C}_{36} ; \mathbf{B}$ - composition of hydrocarbons in the saturated fraction separated from the bitumen extract of sample Ch-21 showing a hydrocarbon interval from $n-\mathrm{C}_{17}$ to $n$ - $\mathrm{C}_{36} ; \mathbf{C}$ - distribution of hopanes $(\mathrm{m} / \mathrm{z}=191)$ in the bitumen extract of sample $\mathrm{Ch}-21 ; \mathbf{D}$ - distribution of steranes $(\mathrm{m} / \mathrm{z}=217)$ in the bitumen extract of sample Ch-17

\section{Podsumowanie badań inkluzji fluidalnych w minerałach skal}

Jednym z celów badań było prześledzenie charakteru inkluzji fluidalnych w możliwie najpełniejszym profilu otworu wiertniczego. Najdłuższy (choć nie całkowicie ciagły) profil uzyskano dla otworu Mo-1 w zakresie głębokości 3027,50-3357,35 m. Efekt wzbudzenia w nadfiolecie jest zaprezentowany na rycinie 2 (patrz str. 726) i ry- cinie 3 (patrz str. 793). Inkluzje fluidalne nie wykazuja fluorescencji w partii ponad złożowei, co jest widoczne na rycinie $2 \mathrm{~A}-\mathrm{D}$. Próbki Ch-18 i Ch-19 to makroskopowo jasno żółta skała całkowicie przesycona węglowodorami. Fluorescencję tej partii przedstawiono na mikrofotografiach preparatów odkrytych. Natomiast nagromadzenia wyraźnie fluoryzujące w barwach biało-niebieskich można zaobserwować w profilu już poniżej tej przesyconej partii. 
Tab. 4. Wskaźniki geochemiczne obliczone na podstawie rozkładu węglowodorów frakcji nasyconej

Table 4. Geochemical parameters calculated based on hydrocarbon distribution of the saturated fraction

\begin{tabular}{|l|c|c|c|}
\hline $\begin{array}{c}\text { Próbka } \\
\text { Sample }\end{array}$ & Pr/Ph & $\mathbf{P r} / \boldsymbol{n}-\mathbf{C}_{\mathbf{1 7}}$ & $\mathbf{P h} / \boldsymbol{n}-\mathbf{C}_{\mathbf{1 8}}$ \\
\hline Ch-17 & 0,11 & 1,09 & 2,03 \\
\hline Ch-21 & 0,20 & 1,08 & 1,86 \\
\hline
\end{tabular}
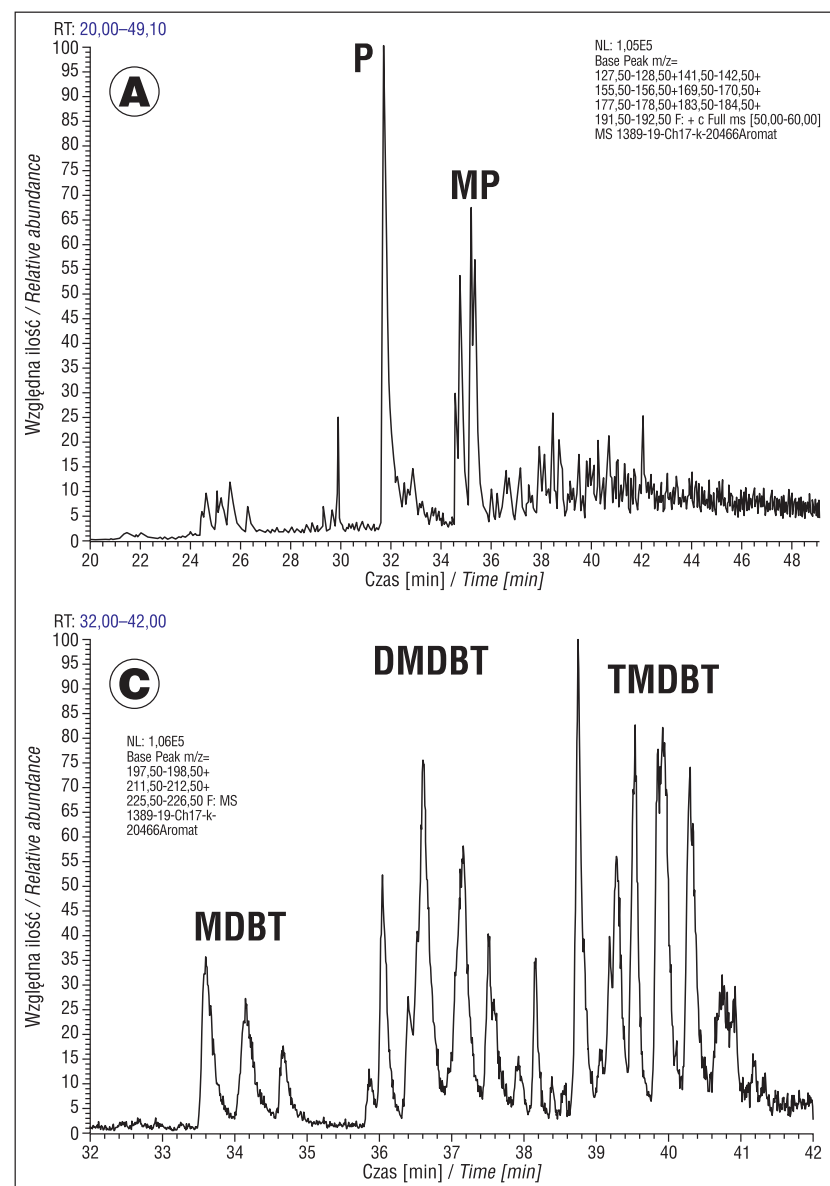

Tab. 5. Wskaźniki geochemiczne obliczone ze składu biomarkerów frakcji aromatycznej

Table 5. Geochemical parameters calculated from biomarkers composition in the aromatic fraction

\begin{tabular}{|l|c|c|c|c|}
\hline $\begin{array}{c}\text { Próbka } \\
\text { Sample }\end{array}$ & MPI-1 & $\mathbf{R}_{\text {(MPI-1) [\%] }}$ & MDR & $\mathbf{R}_{\text {(MDR) [\%] }}$ \\
\hline Ch-17 & 0,38 & 0,63 & 2,91 & 0,72 \\
\hline Ch-21 & 0,77 & 0,86 & 2,73 & 0,71 \\
\hline
\end{tabular}
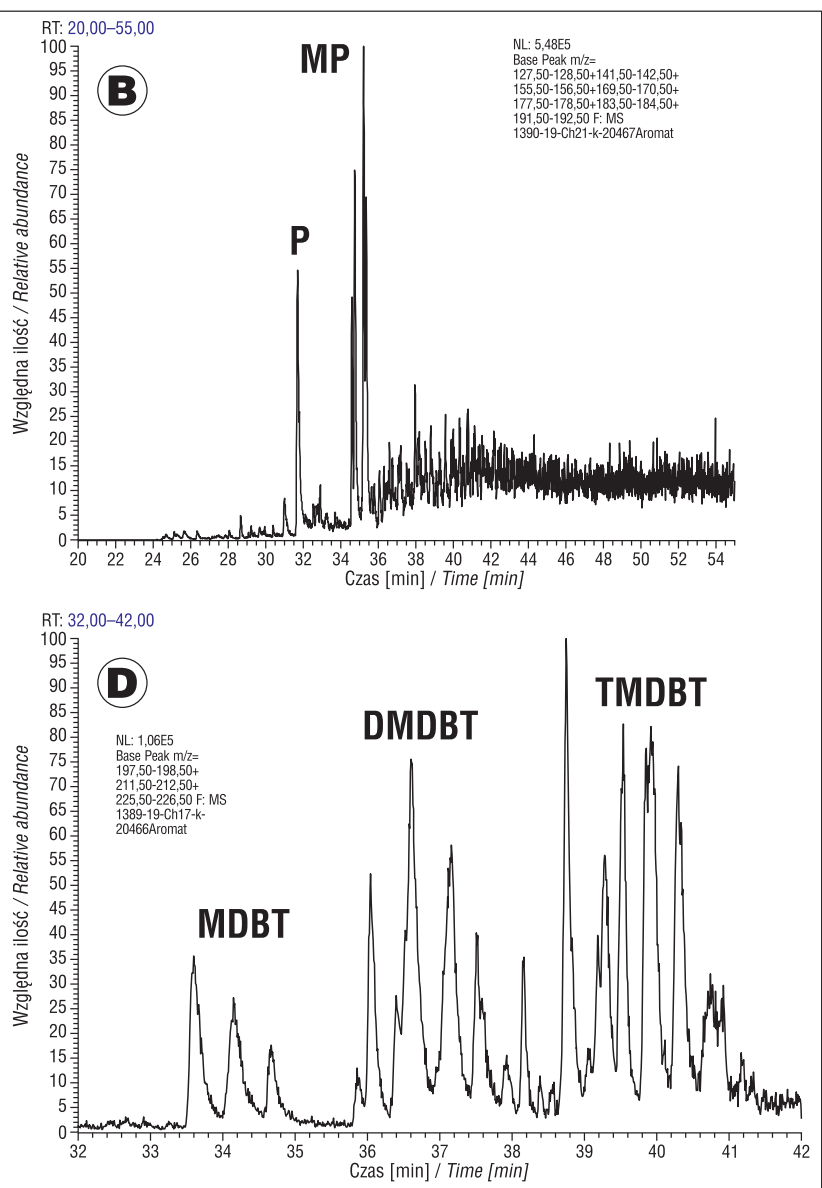

Ryc. 8. Skład frakcji aromatycznej: A - skład fenantrenu i jego pochodnych we frakcji aromatycznej ekstraktu bitumicznego w próbce Ch-17; B - skład fenantrenu i jego pochodnych we frakcji aromatycznej ekstraktu bitumicznego w próbce Ch-21; C - skład związków siarki we frakcji aromatycznej ekstraktu bitumicznego w próbce Ch-17; D - skład związków siarki we frakcji aromatycznej ekstraktu bitumicznego w próbce Ch-21. Objaśnienia skrótów: P - fenantren, MP - metylofenantreny, MDBT - metylodibenzotiofeny, DMDBT dimetylodibenzotiofeny, TMDBT - trimetylodibenzitiofeny

Fig. 8. Composition of the aromatic fraction: $\mathbf{A}$ - composition of phenantrene and its derivatives in the aromatic fraction of bitumen extract in sample Ch-17; B - composition of phenantrene and its derivatives in the aromatic fraction of bitumen extract in sample Ch-21; $\mathbf{C}$ - composition of sulphur compounds in the aromatic fraction of bitumen extract in sample Ch-17; D - composition of sulphur compounds in the aromatic fraction of bitumen extract in sample Ch-17. Abbreviations: $\mathrm{P}$ - phenantrene, $\mathrm{MP}$ - methylophenantrenes, MDBT methylodibenzotiophenes, DMDBT - dimethylodibenzotiophenes, TMDBT - trimetlylodibenzitiophenes

Badania fluorescencji w minerałach i skałach w otworze wiertniczym Mo-1 wykazują obecność świecenia niektórych dwufazowych inkluzji fluidalnych, niebieskawe wzbudzenie (lub całkowity jego brak) w przypadku inkluzji jednofazowych, brak fluorescencji dla niektórych inkluzji dwufazowych oraz zróżnicowane świecenie nagromadzeń bitumicznych w skałach (por. Jarmołowicz-Szulc, 2018).

Jak wynika z uzyskanych rezultatów badań, w zależności od fazowości inkluzji i luminescencji lub jej braku w nadfiolecie $\mathrm{w}$ minerałach ze skał $\mathrm{z}$ otworów regionu $\mathrm{BMB}$ można wyróżnić kilka typów wrostków gazowociekłych (por. Jarmołowicz-Szulc, 2019).

Inkluzje jednofazowe w temperaturze pokojowej, które nie wykazują fluorescencji (patrz tab. 6), homogenizuja w gaz w zakresie temperatur ujemnych: od $-138,5^{\circ} \mathrm{C}$ ) do $-128^{\circ} \mathrm{C}$, co można zinterpretować jako metan z domieszką azotu. Nie można wykluczyć, że niektóre bardzo małe niefluoryzujące inkluzje zauważalne pod mikroskopem w minerałach również mogą zawierać metan. Ich szczegółowa diagnoza była jednakże niemożliwa z uwagi na wielkość wrostków, która uniemożliwiała obserwacje ich wnętrza i przebiegu potencjalnych procesów w trakcie eksperymentów zamrażania i podgrzewania. Lekkie węglowodory są lub mogą też być obecne w inkluzjach roztworów wodnych, na co wskazuje zachowanie pęcherzyków niektórych wrostków w bardzo niskich temperaturach (tworzenie dodatkowych faz i ich homogenizacja - por. ryc. 10). 
Tab. 6. Wyniki badań mikrotermometrycznych dla otworu wiertniczego Mo-1

Table 6. Microthermometric results for the Mo-1 well

\begin{tabular}{|c|c|c|c|}
\hline $\begin{array}{l}\text { Próbka / głębokość [m] } \\
\text { Sample / depth [m] }\end{array}$ & $\begin{array}{l}\text { Skala / mineral } \\
\text { Rock/mineral }\end{array}$ & $\begin{array}{c}\text { Opis fluorescencji / inkluzje } \\
\text { Fluorescence description / inclusions }\end{array}$ & $\begin{array}{l}\text { Mikrotermometria } \\
\text { Microthermometry }\end{array}$ \\
\hline Ch-12 / 3027,5 & $\begin{array}{l}\text { anhydryt }-\mathrm{S} \\
\text { anhydrite }-S\end{array}$ & & \\
\hline Ch-13 / 3031,5 & $\begin{array}{l}\text { anhydryt wtrącenia w dolomicie } \\
\text { inclusions of anhydrite in dolomite }\end{array}$ & $\begin{array}{l}\text { długie, geometryczne } \\
\text { long, geometric in shape }\end{array}$ & $?-64,2^{\circ} \mathrm{C}$ \\
\hline Ch-13 / 3031,5 & $\begin{array}{l}\text { dolomit } \\
\text { dolomite }\end{array}$ & $\begin{array}{l}\text { dwufazowe, bezkształtne } 3 \text { FIA / AQFI } \\
\text { two-phase, shapeless }\end{array}$ & $\begin{array}{l}\mathrm{Th}=133^{\circ} \mathrm{C} \\
\mathrm{Th}=116,8^{\circ} \mathrm{C} \text { zanik pęcherzyka / } \\
\text { bubble vanishing } \\
\mathrm{Tm}=-3,8^{\circ} \mathrm{C}\end{array}$ \\
\hline Ch-14 / 3035,3 & $\begin{array}{l}\text { pojedyncze kryszały tabliczkowate } \\
\text { anh. } \\
\text { separated tabular crystals }\end{array}$ & $\begin{array}{l}\text { jednofazowe; L1 + L2 } \\
\text { one-phase }\end{array}$ & $\begin{array}{l}\mathrm{Th}=16,5^{\circ} \mathrm{C} \\
\mathrm{Th}=-79^{\circ} \mathrm{C}\end{array}$ \\
\hline Ch-15 / 3039,3 & $\begin{array}{l}\text { anhydryt } \\
\text { anhydrite }\end{array}$ & $\begin{array}{l}\text { pozornie jednofazowe, porozciągane } 7 \\
\text { FIA } \\
\text { seemingly one-phase, stretched }\end{array}$ & $\begin{array}{l}\text { Th1 }=-138,5^{\circ} \mathrm{C} \\
\text { Th1 }=-138^{\circ} \mathrm{C} \\
\text { Th2 }=166^{\circ} \mathrm{C} \\
\text { Th2 }=166,9^{\circ} \mathrm{C}\end{array}$ \\
\hline Ch-15 / 3039,3 & $\begin{array}{l}\text { anhydryt } \\
\text { anhydrite }\end{array}$ & $\begin{array}{l}\text { dwufazowa, bezkształtna ?jasno żółta } \\
\text { two-phase shapeless? bright yellow }\end{array}$ & $\begin{array}{l}\mathrm{Th}=180^{\circ} \mathrm{C} \\
\text { od } 164,8^{\circ} \mathrm{C} \text { zanik / } \\
\text { vanishing from }\end{array}$ \\
\hline Ch-15 / 3039,3 & $\begin{array}{l}\text { anhydryt } \\
\text { anhydrite }\end{array}$ & $\begin{array}{l}\text { pozornie jednofazowe; porozciagane } \\
7 \text { FIA } \\
\text { seemingly one-phase, stretched }\end{array}$ & $\begin{array}{l}\text { Th pecherzyka }=-138,5^{\circ} \mathrm{C} \\
\text { Th inkluzji }=166,9^{\circ} \mathrm{C} \\
\text { Th of bubble }=-138.5^{\circ} \mathrm{C} \\
\text { Th of inclusion }=166.9^{\circ} \mathrm{C}\end{array}$ \\
\hline Ch-16 / 3044,0 & $\begin{array}{l}\text { dolomitowy pakston ooidowy - S } \\
\text { dolomitic ooidal packstone }-S\end{array}$ & & \\
\hline Ch-20 / 3090,45 & $\begin{array}{l}\text { dolomitowy greinston } \\
\text { onkoidowy }-\mathrm{S} \\
\text { dolomitic oncoidal grainstone }-S\end{array}$ & $\begin{array}{l}\text { inkluzje jednofazowe; kształt } \\
\text { geometryczny } \\
\text { one-phase inclusions; geometric shape }\end{array}$ & $\begin{array}{l}\text { duża dwójłomność uniemożliwia } \\
\text { śledzenie procesów } \\
\text { huge birefrigence disables } \\
\text { observations of processes }\end{array}$ \\
\hline Ch-22 / 3096,4 & $\begin{array}{l}\text { anhydryt } \\
\text { anhydrite }\end{array}$ & $\begin{array}{l}\text { inkluzje jednofazowe; kształt } \\
\text { geometryczny } \\
\text { one-phase inclusions; geometric in shape }\end{array}$ & $\mathrm{Th}=-128,0^{\circ} \mathrm{C}$ \\
\hline Ch-23 / 3357,35 & $\begin{array}{l}\text { anhydryt }-\mathrm{S} \\
\text { anhydrite }-S\end{array}$ & $\begin{array}{l}\text { b. małe nieświecące FI } \\
\text { very small non-fluorescent inclusions }\end{array}$ & \\
\hline Ch-24 / 3402,7 & $\begin{array}{l}\text { anhydryt }-\mathrm{S} \\
\text { anhydrite }-S\end{array}$ & & \\
\hline Ch-25 / 3413,8 & $\begin{array}{l}\text { greinston ooidowy }-\mathrm{S} \\
\text { ooidal grainstone }-S\end{array}$ & & \\
\hline
\end{tabular}

$\mathrm{S}$ - płytka cienka, opis w tab. 1.

$S$ - thin section, for description see Table1.

Inkluzje dwufazowe wykazujące fluorescencję są inkluzjami ropy naftowej, podczas gdy te dwufazowe bez wzbudzenia wypełnione są roztworami soli (Jarmołowicz-Szulc, 2018).

Podobnie jak w skałach dolomitu głównego innych otworów obszaru BMB, temperatury homogenizacji obu rodzajów inkluzji dwufazowych mieszczą się w różnym zakresie dla roztworów solankowych i węglowodorów, ale na ogół dwufazowe inkluzje ropy homogenizują w przedziale temperatur powyżej $100^{\circ} \mathrm{C}$. Dotyczy to zarówno inkluzji o charakterze wodnym, jak i ciekłych weglowodorów, przy czym inkluzje wodne (AQFI) wydają się homogenizować $\mathrm{w}$ nieco niższych temperaturach niż inkluzje ropy.

Sądząc z obserwacji petrograficznych, badań mikroskopowych inkluzji w świetle przechodzącym i odbitym oraz na podstawie oznaczeń mikrotermometrycznych do głębokości ok. $3044 \mathrm{~m}$, w spoiwie skał typu pakstonu lub greinstonu ooidowego są zamknięte jednofazowe inkluzje, które nie wykazują fluorescencji, a ich wypełnienie można zdiagnozować jako metan $\mathrm{z}$ domieszkami $\left(\mathrm{CH}_{4}+\mathrm{N}_{2}+(\right.$ ? $\left.) \mathrm{CO}_{2}\right)$. Ich obecność wskazuje na występowanie lub/i kierunek migracji gazu. W stropowych partiach otworu $(3027,5-$ $3039,3 \mathrm{~m}$ ) metan występuje już przeważnie jako pęcherz w inkluzjach solankowych wypełnionych roztworem o nie- wysokim stężeniu $\left(\mathrm{Tm}=-3,8^{\circ} \mathrm{C}\right.$, zasolenie $-6,1 \%$ wag. ekw. $\mathrm{NaCl}$, gęstość fluidu ok. $0,98 \mathrm{~g} / \mathrm{cm}^{3}$; tab. 7) i/lub w charakterze domieszki do innego gazu. Interpretując wyniki prezentowane $\mathrm{w}$ tabelach, można powiedzieć, że w pełni zdiagnozowany mikrotermometrycznie metan jest zamknięty w postaci małych inkluzji w anhydrycie już od głębokości ok. 3357 m (Mo-1, pr. Ch-23 / 3357,35 m). Wyżej występuje rzadziej, w zdolomityzowanych oobiosparytach z domieszką anhydrytu, scementowanych dolomitem wraz z bardziej obfitą solanką (zakres 3025-3042 m, próbki Ch-12 do Ch-15). Tym samym inkluzje w profilu pionowym wskazują kierunek akumulacji złożowej.

\section{Podsumowanie badań bituminów}

Skład węglowodorów frakcji nasyconej (ryc. 7A-B, tab. 4) oznacza algowe źródło substancji organicznej. Wartość wskaźnika $\mathrm{Pr} / \mathrm{Ph}$ pomiędzy 0,11 a 0,20 wskazuje na warunki redukcyjne środowiska depozycji substancji organicznej (tab. 4; Hunt, 1995; Peters i in., 2005).

We frakcji nasyconej, wśród steranów jest zauważalna dominacja C29 steranów, co wskazuje na udział algowej materii organicznej, której źródłem są zielone algi (Kodner i in., 2008). Zawartość obu grup biomarkerów frakcji 

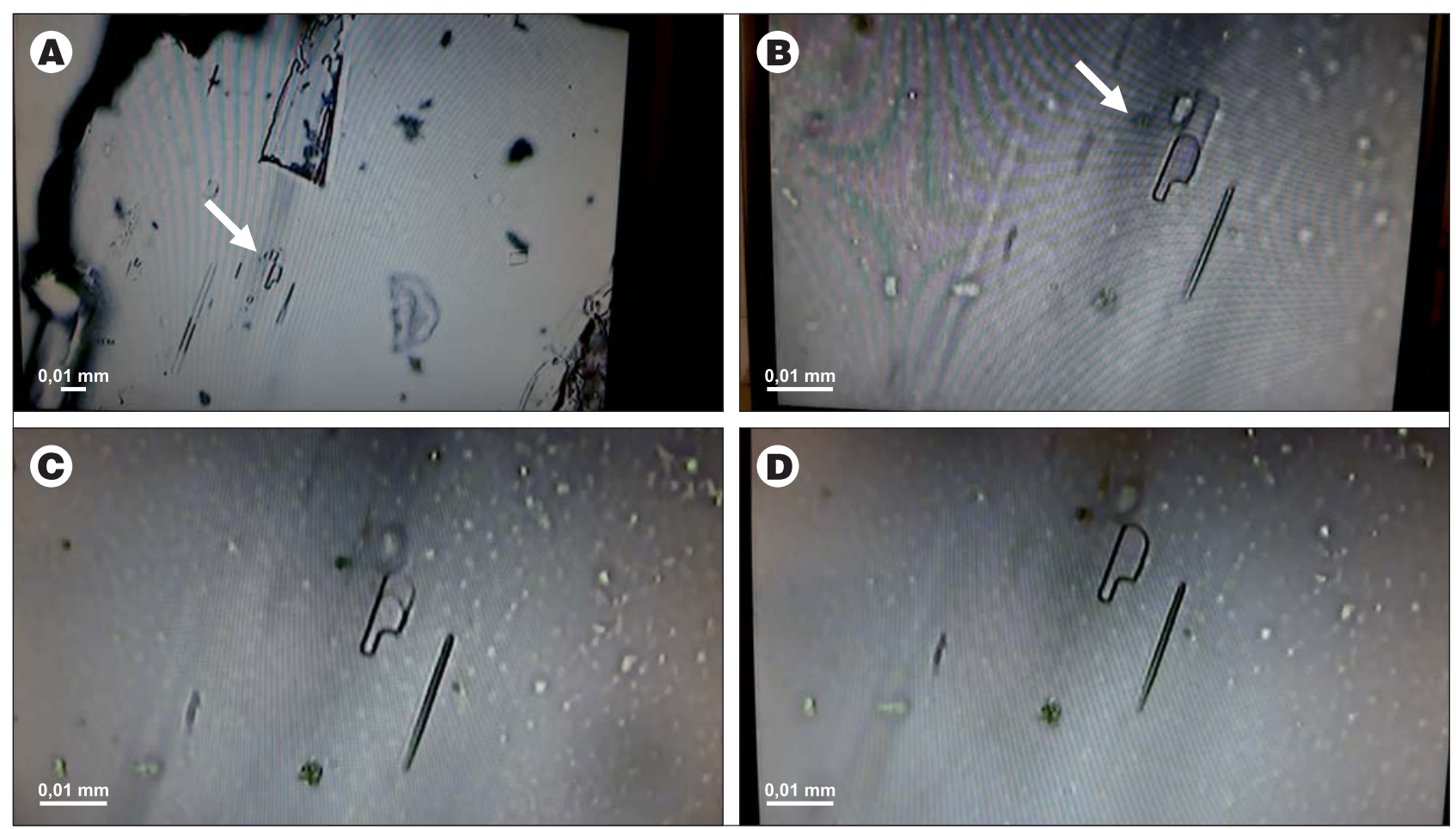

Ryc. 9. Badania mikrotermometryczne inkluzji w anhydrycie (zamrażanie i podgrzewanie pęcherzyka) w otworze wiertniczym Mo-1. A - dwufazowa inkluzja w anhydrycie (strzałka) i grupa wydłużonych inkluzji (FIA = 7), próbka Ch-15, gł. 3039,3 m. Światło przechodzące, Linkam, temperatura pokojowa; B - ta sama dwufazowa inkluzja w anhydrycie (strzałka) pod obiektywem 50×; C - zamrożenie pęcherzyka inkluzji w temperaturach głęboko ujemnych powoduje rozdział faz, temperatura $-196^{\circ} \mathrm{C}$; $\mathbf{D}-$ homogenizacja faz w pęcherzyku, temperatura $-138,5^{\circ} \mathrm{C}$

Fig. 9. Microthermometric studies of inclusions in anhydrite (freezing and heating of a bubble) in the Mo-1 well. A - two-phase inclusion in anhydrite (arrow) and a group of elongated inclusions (FIA = 7), sample Ch-15, depth $3039.3 \mathrm{~m}$. Transparent light, Linkam, room temperature; $\mathbf{B}$ - same two-phase inclusion in anhydrite (arrow) under $50 \times$ objective; $\mathbf{C}$ - freezing of the bubble at very low temperatures causes separation of phases, temperature $-196^{\circ} \mathrm{C} ; \mathbf{D}$ - homogenization of phases in the bubble, temperature $-138.5^{\circ} \mathrm{C}$

Tab. 7. Wartości zasolenia fluidów w dwufazowych inkluzjach AQFI w otworze Mo-1 i w wybranym otworze porównawczym Table 7. Fluid salinities of AQFI in the Mo-1 well and in the selected comparative borehole

\begin{tabular}{|c|c|c|c|c|c|c|}
\hline $\begin{array}{c}\text { Otwór } \\
\text { Well }\end{array}$ & $\begin{array}{l}\text { Próbka / głębokość [m] } \\
\text { Sample / depth [m] }\end{array}$ & $\begin{array}{l}\text { Th } \\
{\left[{ }^{\circ} \mathrm{C}\right]}\end{array}$ & $\begin{array}{l}\text { Tm } \\
{\left[{ }^{\circ} \mathrm{C}\right]}\end{array}$ & $\begin{array}{l}\text { \% wag. ekw. } \mathrm{NaCl} \\
\mathrm{NaCl} \text { weight\% eq. }\end{array}$ & $\begin{array}{l}\text { Molowość } \\
\text { Molality }\end{array}$ & $\begin{array}{c}\text { Gęstość fluidu }\left[\mathrm{g} / \mathrm{cm}^{3}\right] \\
\text { Fluid density }\left[\mathrm{g} / \mathrm{cm}^{3}\right]\end{array}$ \\
\hline $\mathrm{Bu}-9$ & Ch-43 / 3123,85 & 159,5 & $-7,4$ & 10,978 & 2,11 & 0,988 \\
\hline $\mathrm{Bu}-9$ & Ch-11 / 3128,15 & 114,0 & $-6,8$ do 4,3 & 10,228 do 6,615 & 1,95 do 1,25 & 1,020 do 0,996 \\
\hline Mo-1 & Ch-13 / 3031,5 & 133,0 & $-3,8$ do 116,8 & 6,075 & 1,107 & 0,977 do 0,989 \\
\hline
\end{tabular}

\begin{tabular}{|c|c|c|}
\hline $\begin{array}{l}\text { MINERAŁY/ PROCESY } \\
\text { DIAGENETYCZNE } \\
\text { MINERALS/DIAGENETIC } \\
\text { PROCESSES }\end{array}$ & $\begin{array}{l}\text { EODIAGENEZA } \\
\text { EODIAGENESIS }\end{array}$ & $\begin{array}{c}\text { MEZODIAGENEZA } \\
\text { MESODIAGENESIS }\end{array}$ \\
\hline $\begin{array}{l}\text { kalcyt mikrytowy } \\
\text { micritic calcite }\end{array}$ & ש & \\
\hline $\begin{array}{l}\text { kalcyt sparytowy } \\
\text { sparry calcite }\end{array}$ & 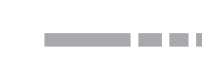 & (1) \\
\hline $\begin{array}{l}\text { kompakcja mechaniczna } \\
\text { mechanical compaction }\end{array}$ & & 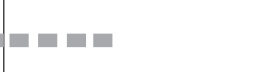 \\
\hline $\begin{array}{l}\text { rozpuszczanie } \\
\text { dissolution }\end{array}$ & שே & 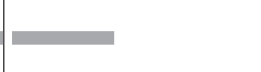 \\
\hline $\begin{array}{l}\text { dolomityzacja } \\
\text { dolomitization }\end{array}$ & 므 & 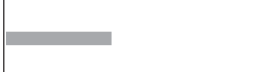 \\
\hline $\begin{array}{l}\text { dolomit sparytowy } \\
\text { sparry dolomite }\end{array}$ & & F \\
\hline $\begin{array}{l}\text { anhydryt } \\
\text { anhydrite }\end{array}$ & 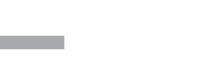 & 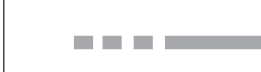 \\
\hline $\begin{array}{l}\text { kompakcja chemiczna } \\
\text { chemical compaction }\end{array}$ & & $\square \square \square$ \\
\hline
\end{tabular}

Ryc. 10. Sekwencja diagenetyczna osadów cechsztynu Fig. 10. Diagenetic sequence of the Zechstein deposits nasyconej jest bardzo mała, a nawet śladowa, co wiąże się $\mathrm{z}$ niewielką zawartością TOC i węglowodorów.

We frakcji aromatycznej nie występują (ewentualnie w minimalnych ilościach) pochodne naftalenu. W badanych próbkach stwierdzono fenantren i jego metylowe pochodne w różnych stosunkach ilościowych względem siebie. Zauważalna jest wyraźna dominacja metylofenantrenów nad fenantrenem w próbce Ch-17 (gł. 3056,5 m), co jest związane z niższym stopniem dojrzałości termicznej niż w próbce Ch-21 (gł. 3096,4 m).

Wartość wskaźnika MP-1 frakcji aromatycznej, obliczonego na podstawie rozkładu fenantrenu i jego metylowych pochodnych w przeliczeniu na równowartość refleksyjności witrynitu, wskazuje na główną fazę okna ropnego, przy nieco bardziej zaawansowanych procesach w próbce Ch-21.

Wyniki badań geochemicznych dla otworu Mo-1 potwierdzają ogólny trend w akumulacji ropy i gazu w otworach złoża BMB (Kotarba, Wagner, 2007; Kosakowski, Krajewski, 2013). 


\section{WNIOSKI}

1. W historii diagenezy skał w otworze można wyróżnić eo- i mezodiagenezę. Kalcyt, dolomit i anhydryt, które wypełniają puste przestrzenie porowe lub mikroszczeliny są związane z późniejszym etapem rozwoju skał. Obok cementacji ważnym procesem diagenetycznym było rozpuszczanie cementów i ziarn węglanowych. W skałach obserwowano efekty kompakcji mechanicznej i kompakcji chemicznej.

2. W zależności od fazowości inkluzji i luminescencji lub jej braku w nadfiolecie w minerałach można wyróżnić trzy typy wrostków wypełnionych fluidami o różnym charakterze. Inkluzje jednofazowe w temperaturze pokojowej, które nie wykazują fluorescencji, homogenizujące w gaz $\mathrm{w}$ zakresie temperatur ujemnych: od $-138,5$ do $-128^{\circ} \mathrm{C}$, zinterpretowano jako metan $\mathrm{z}$ domieszką azotu. Inkluzje dwufazowe wykazujące fluorescencję są inkluzjami ropy naftowej, podczas gdy dwufazowe bez wzbudzenia są wypełnione roztworami soli. Solanka ma zasolenie 6,1 \%wag. ekw. $\mathrm{NaCl}$, gęstość fluidu ok. $0,98 \mathrm{~g} / \mathrm{cm}^{3}$.

3. Wyniki badań geochemicznych bituminów w skałach wskazują na niezbyt wysoką dojrzałość materii organicznej, a ich zmienność w pionie wraz z rozkładem rodzajów inkluzji fluidalnych potwierdza ogólny trend akumulacji ropy i gazu w otworach złoża BMB.

Prace badawcze przeprowadzono w ramach tematu statutowego PIG-PIB poz.pl. 61.2805.1704.00.0. Autorki dziękują zespołowi PGNiG za udostępnienie próbek do badań i zgodę na niniejszą publikację. Uwagi i sugestie recenzentów - L. Marynowskiego i P. Kosakowskiego wpłynęły na znaczną poprawę jakości manuskryptu, za co autorki wyrażają wdzięczność.

\section{LITERATURA}

BAKKER R.J. 2003 - Package FLUIDS 1. Computer programs for analysis of fluid inclusion data and for modeling bulk fluid properties. Chem. Geol., 194: 3-23.

BAKKER R.J., BROWN P.E. 2003 - Computer modeling in fluid inclusion research. [W:] Samson I., Anderson A., Marshall D. (red.), Fluid inclusions: analysis and interpretation. Short Course, Mineral. Assoc. Canada, 32: 185-203

BROWN P.E. 1989 - Flincor: A microcomputer program for the reduction and investigation of fluid inclusion data. Am. Mineral., 74: 1390-1393.

CZEKALSKI E., KWOLEK K., MIKOŁAJEWSKI Z. 2010 - Złoża węglowodorów w utworach cechsztyńskiego dolomitu głównego (Ca2) na bloku Gorzowa. Prz. Geol., 58 (8): 695-703.

DEPOWSKA A., DROP K. 1997 - Dolomit główny w rejonie złoża BMB. Materiały Konferencji „Rozwój polskiej myśli naukowej w poszukiwaniach naftowych", AGH, 25-26 września 1997, Kraków: 286-288. GĄSIEWICZ A., WICHROWSKA M., DARŁAK B. 1998 - Sedymentacja i diageneza a właściwości zbiornikowe utworów dolomitu głównego (Ca2) w polskim basenie cechsztyńskim. [W:] Narkiewicz M. (red.), Analiza basenów sedymentacyjnych Niżu Polskiego. Pr. Państw. Inst. Geol., 165: 195-206.

GEORGE S.C., MANZUR A., LIU K., VOLK H. 2002 - The effect of minor to moderate biodegradation on $\mathrm{C} 5$ to $\mathrm{C} 9$ hydrocarbons in crude oils. Org. Geochem., 33: 1293-1317.

GOLDSTEIN R.H. 2001 - Fluid inclusions in sedimentary and diagenetic systems. Lithos, 55: 159-193.

GOLDSTEIN R.H., REYNOLDS T.J. 1994 - Systematics of fluid inclusions in diagenetic minerals. SEPM Short Course 31, Tulsa.

GÓRSKI M., TRELA M. 1997 - Barnówko-Mostno-Buszewo (BMB) the greatest oil field in Poland: Geometry and reservoir description based on 3D survey. Prz. Geol., 45 (7): 685-692.
HUNT J.M. 1995 - Petroleum Geochemistry and Geology. New York. JARMOŁOWICZ-SZULC K. 2009 - Fluid inclusion analysis in the filling of the pore space in the Rotliegend rocks in selected regions of the Polish Lowlands. Prz. Geol., 57 (4): 666-676.

JARMOŁOWICZ-SZULC K. 2016 - Hydrocarbon inclusions in cements of sedimentary rocks and in vein minerals - characteristics and significance. Biul. Państw. Inst. Geol., 466: 87-101.

JARMOŁOWICZ-SZULC K. 2018 - Remarks on the use of inclusions in the minerals in the rocks of hydrocarbon fields. Inter. J. Petrol. Sci. Eng., 3 (1): 9-10. Doi: 10.15406/ipcse.2018.03.00069

JARMOŁOWICZ-SZULC K. 2019 - Wybrane elementy badań petrologicznych w obrębie złoża BMB. Prz. Geol., 67 (3): 161-164.

KARNKOWSKI P.H. 2000 - Rozwój prac poszukiwawczych w utworach cechsztynu na Niżu Polskim w latach 1945-2000. Prz. Geol., 48 (5): 423-428.

KARNKOWSKI P.H. 2007 - Petroleum provinces in Poland. Prz. Geol., 12 (1): 1061-1067.

KODNER R.B., PEARSON A., SUMMONS R.E., KNOLL A.H. $2008-$ Sterols in red and green algae: quantification, phylogeny, and relevance for the interpretation of geologic steranes. Geobiology, 6 (4): 411-420. KOSAKOWSKI P., KRAJEWSKI M. 2013 - Hydrocarbon potential of the Zechstein Main Dolomite in the western part of the Wielkopolska platform, SW Poland: New sedimentological and geochemical data. Mar. Petrol. Geol., 49: 99-120.

KOTARBA A., WAGNER R. 2007 - Generation potential of the Zechstein Main Dolomite (Ca2) carbonates in the Gorzów WielkopolskiMiędzychód-Lubiatów area: Geological and geochemical approach to microbial-algal source rock. Prz. Geol., 55 (12): 1025-1036.

MAMCZUR S., RADECKI S., WOJTKOWIAK Z. 1997 - O najwiekszym złożu ropy naftowej w Polsce Barnówko-Mostno-Buszewo (BMB). Prz. Geol., 45 (6): 582-588.

MATYASIK I. 2009 - System naftowy jednostki śląskiej i dukielskiej w rejonie Jasło-Krosno-Sanok. Nafta-Gaz, 3: 201-206.

PERYT T.M., DYJACZYŃSKI K. 1991 - An isolated carbonate bank in the Zechstein Main Dolomite Basin in western Poland. J. Petrol. Geol., 14: 445-458.

PERYT T.M., PIĄTKOWSKI T.S. 1977 - Procesy neomorficzne w utworach onkolitowych wapienia cechsztyńskiego syneklizy perybałtyckiej. Kwart. Geol., 21 (2): 257-265.

PETERS K.E., WALTER C.C., MOLDOVAN J.M. 2005 - The biomarker guide. Cambridge University Press.

PIKULSKI L. 1998 - Sedymentacja oraz rozwój litofacjalny utworów dolomitu głównego (Ca2) w rejonie złoza Barnówko-Mostno-Buszewo (BMB), zachodnia Polska. Prz. Geol., 46 (5): 426-435.

PIKULSKI L., WOLNOWSKI T. 2000 - Geological analysis of the main Dolomite Formation (Ca2) in Western Poland. American Association of Petroleum Geologists Search and Discovery Article. AAPG/EAGE International Research Conference, E1 Paso, Texas, Oct. 1-5, 2000, 53.

RADKE M., WELTE D.H., WILLSCH D. 1986 - Maturity parameters based on aromatic hydrocarbons: influence of the organic matter type. Org. Geochem., 10: 51-63.

ROEDDER E. 1984 - Fluid inclusions. Reviews in Mineralogy. Mineral. Soc. Am. 12, 646 p.

SHEPHERD T.J., RANKIN A.H., ALDERTON D.H. 1985 - A practical guide to FI studies. Blackie. New York.

SŁOWAKIEWICZ M., MIKOŁAJEWSKI Z. 2011 - Upper Permian Main Dolomite microbial carbonates as potential source rocks for hydrocarbons (W Poland). Mar. Petrol. Geol., 28 (8): 1572-1591.

SYLWESTRZAK J. 1999 - Litologia osadów i efekty działania procesów diagenetycznych. Perm górny-cechsztyn. [W:] Maliszewska A. (red.), Diageneza osadów permu górnego i mezozoiku Kujaw. Pr. Państw. Inst. Geol., 167: 9-21.

THOMPSON K.F.M. 1987 - Fractionated aromatic petroleum and the generation of gas-condensates. Org. Geochem., 11: 573-590.

WAGNER R., DYJACZYŃSKI K., PAPIERNIK B., PERYT T.M., PROTAS A. 2000 - Mapa paleogeograficzna dolomitu głównego. [W:] Kotarba M. (red.) Potencjał i bilans weglowodorowy utworów dolomitu głównego basenu permskiego Polski. Arch. BG Geonafta, Warszawa. WEIL W., RADECKI S., KARNKOWSKI P., JASTRZĘBSKI M. 1994 Poszukiwanie ropy naftowej i gazu ziemnego w 1993 roku i zamierzenia na przyszłość. Nafta-Gaz, 50: 227-233.

Praca wpłynęła do redakcji 29.05.2020 r. Akceptowano do druku 23.09.2020 r. 


\section{Studium petrologiczno-mineralogiczno-geochemiczne skal}

w profilu dolomitu głównego w otworze Mo-1 (patrz str. 780)

A petrological, mineralogical and geochemical study of the Main Dolomite in the Mo-1 borehole (see p. 780)
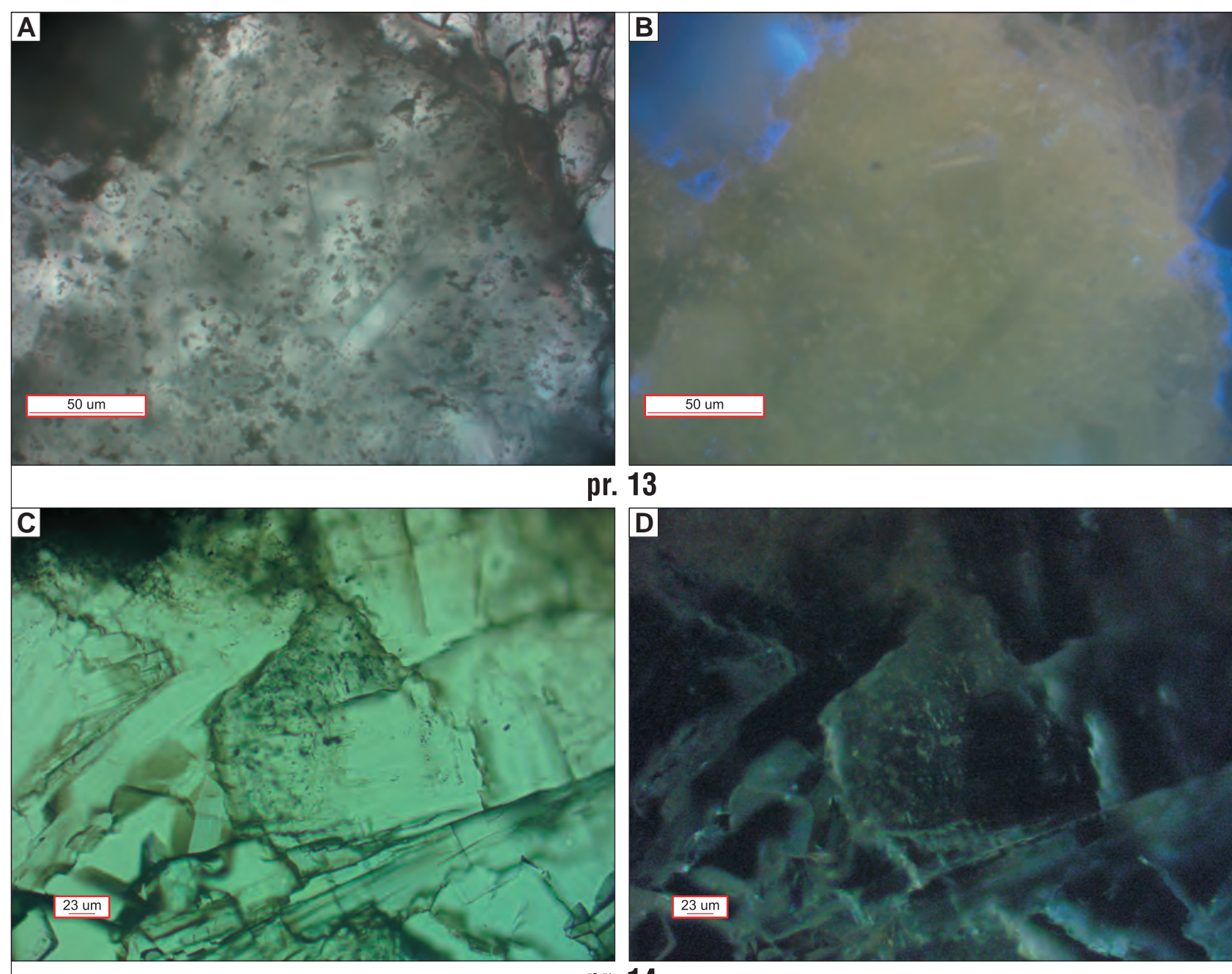

\section{3}

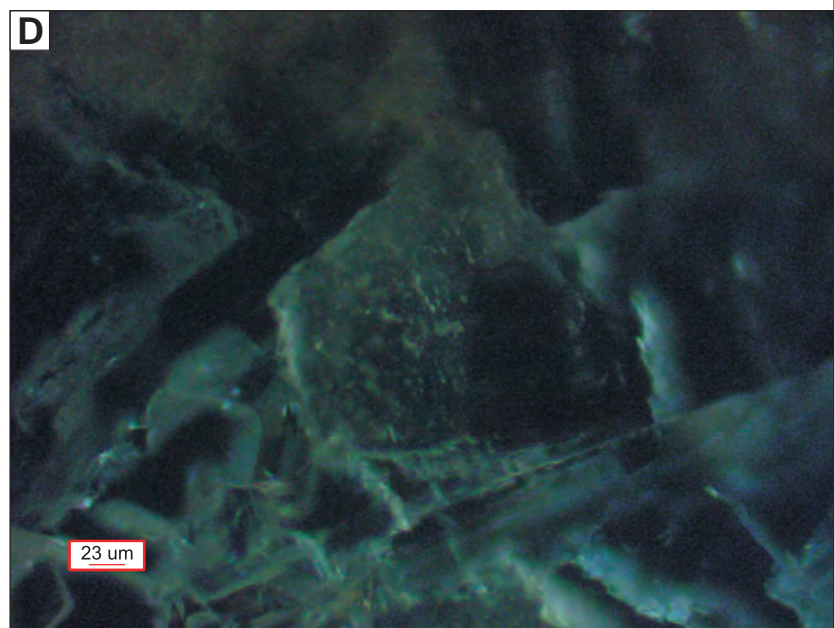

pr. 14
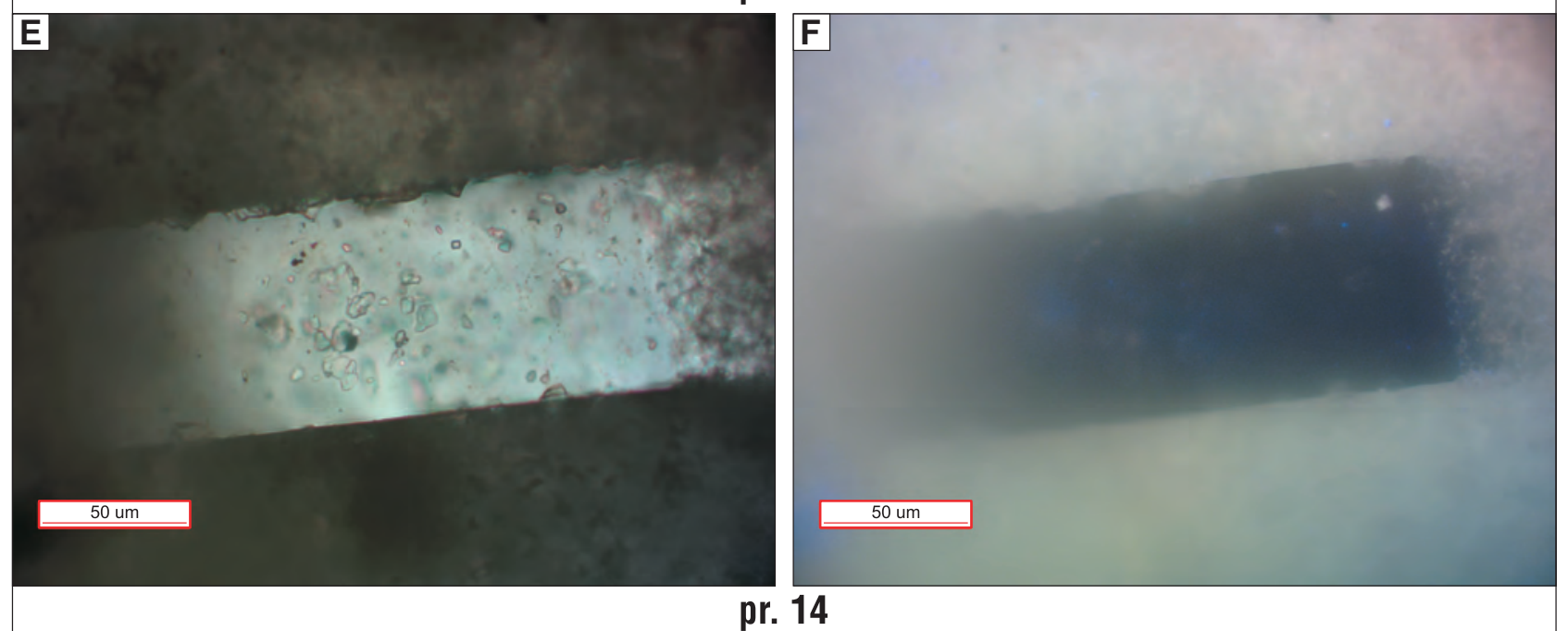

Ryc. 2. Obraz inkluzji w minerałach w otworze Mo-1: A, C, E - w świetle przechodzącym; B, D, F - odbitym (UV)

Fig. 2. Photomicrographs of fluid inclusions in minerals in the Mo-1 well: A, C, E - in polarized light; B, D, F - in reflected light (UV fluorescence) 


\section{Studium petrologiczno-mineralogiczno-geochemiczne skal}

w profilu dolomitu glównego w otworze Mo-1 (patrz str. 780)

A petrological, mineralogical and geochemical study of the Main Dolomite in the Mo-1 borehole (see p. 780)
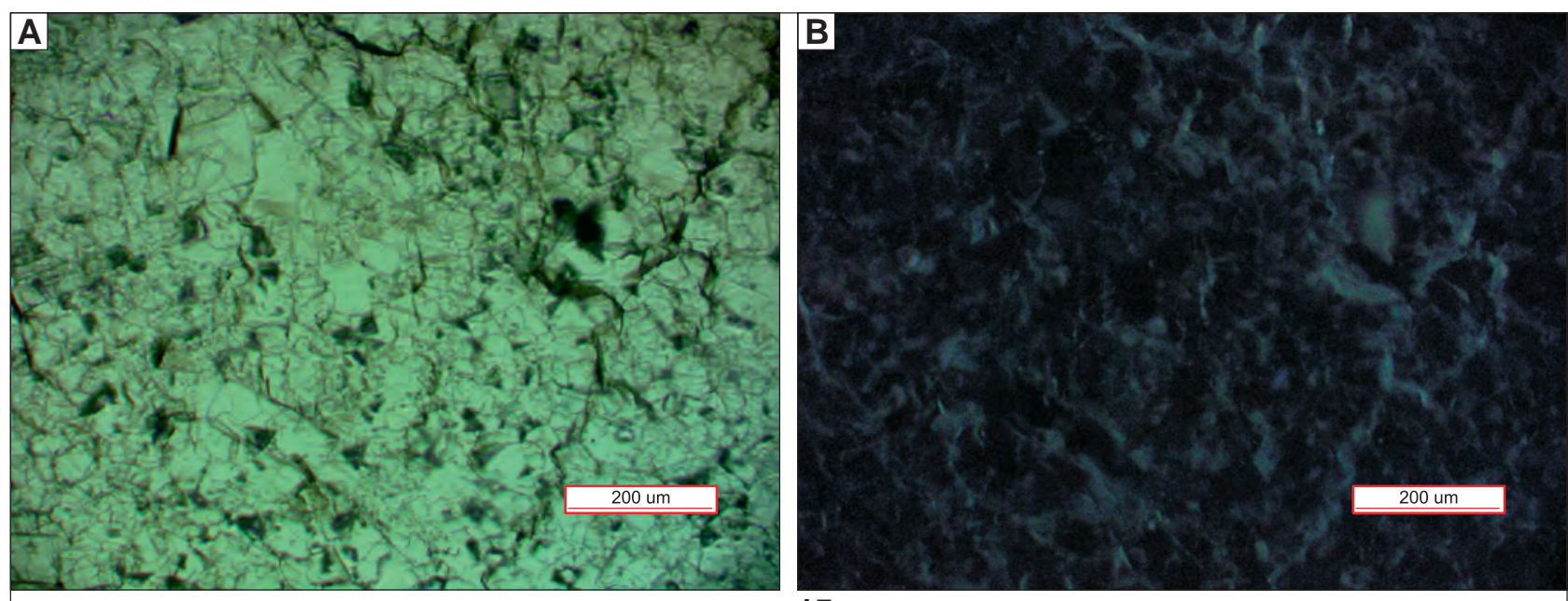

pr. 15
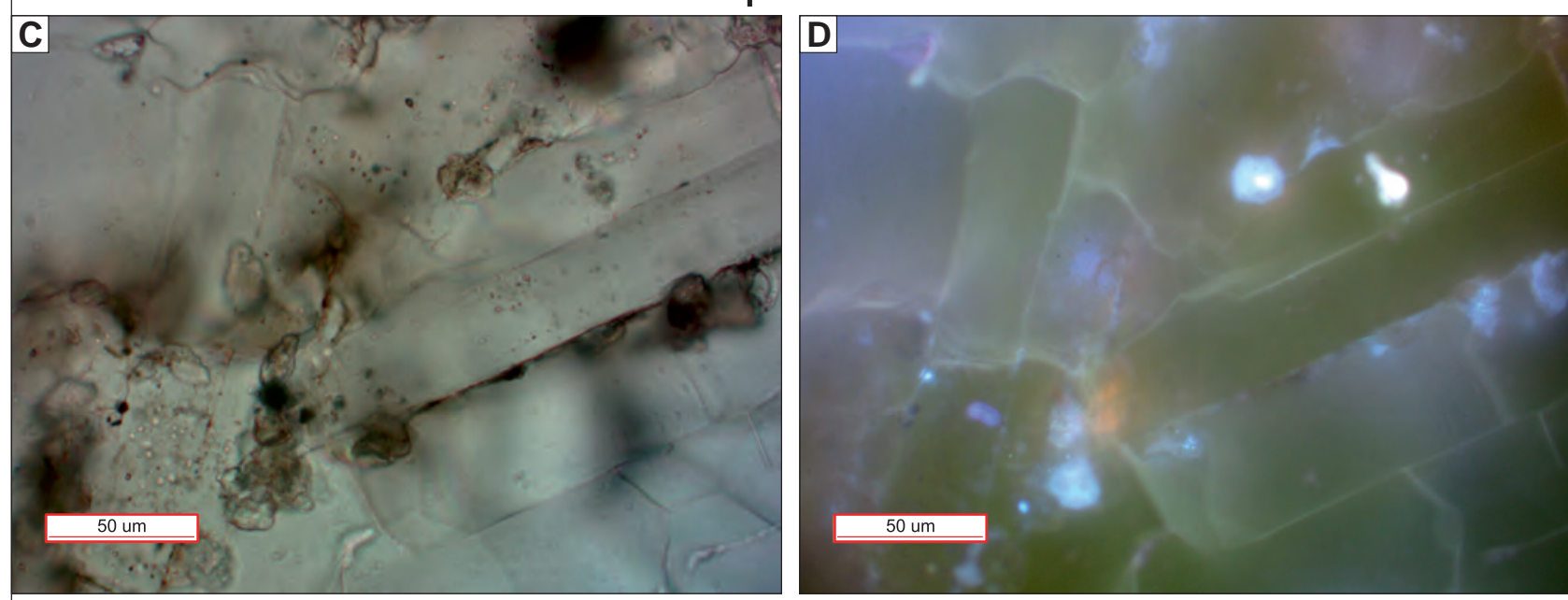

pr. 23
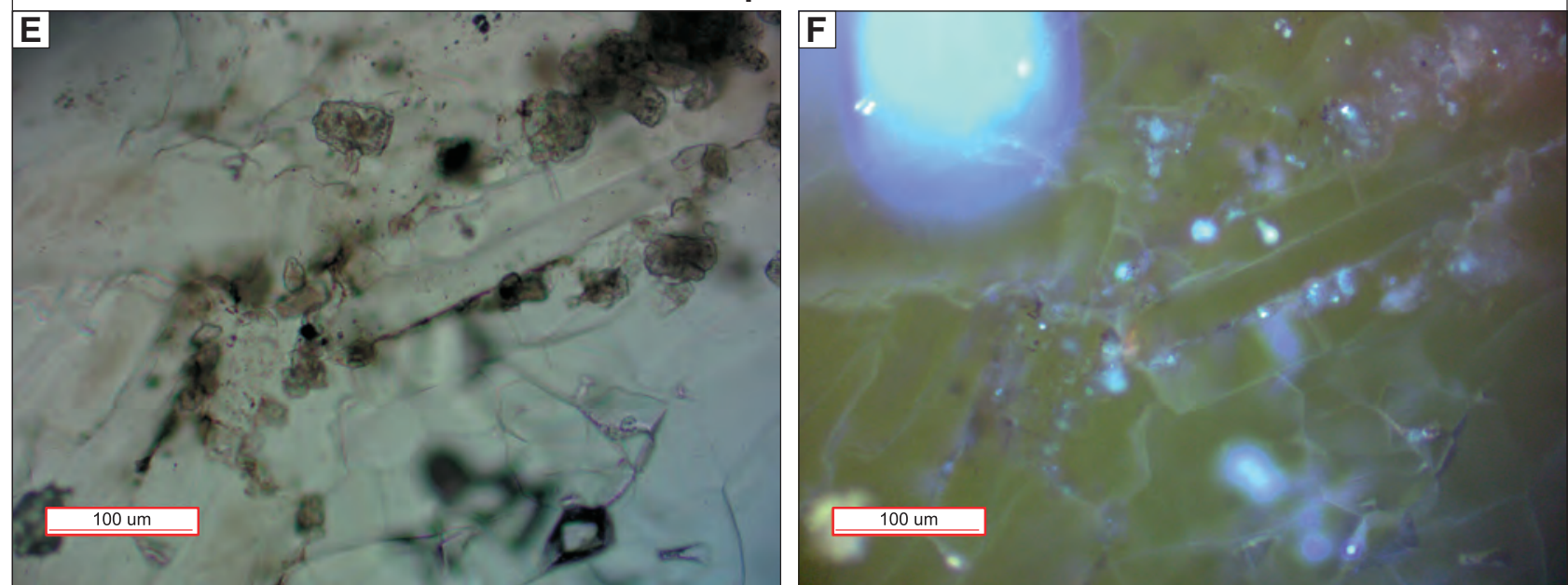

pr. 23

Ryc. 3. Obraz inkluzji w minerałach w otworze Mo-1, próbki 15 i 23: A, C, E - w świetle przechodzącym; B, D, F - odbitym (UV)

Fig. 3. Photomicrographs of fluid inclusions in minerals in the Mo-1 well, samples 15 and 23: A, C, E - in polarized light; B, D, F - in reflected light (UV fluorescence) 